\title{
Recently formed secondary copper minerals as indicators of geochemical conditions in an abandoned mine in Radzimowice (SW Poland)
}

\author{
Rafał SIUDA ${ }^{1, *}$ and Łukasz KRUSZEWSKI ${ }^{2}$ \\ 1 Institute of Geochemistry, Mineralogy and Petrology, University of Warsaw, Żwirki i Wigury 93, 02-089 Warszawa, Poland \\ 2 Institute of Geological Sciences, Polish Academy of Sciences, Twarda 51/55, 00-818 Warszawa, Poland
}

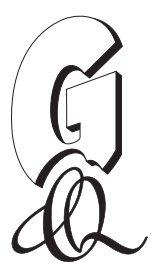

Siuda R. and Kruszewski $Ł$. (2013) Recently formed secondary copper minerals as indicators of geochemical conditions in an abandoned mine in Radzimowice (SW Poland). Geological Quarterly, 57 (4): 583-600, doi: 10.7306/gq.1114

\begin{abstract}
An occurrence of twelve recently formed secondary copper minerals (SCM) was observed in underground workings of an abandoned Cu-As-Au mine in Radzimowice. The minerals, mainly sulphate species, were identified using Powder X-Ray Diffraction (PXRD), scanning electron microscope with energy dispersive spectroscopy system (SEM-EDS) and electron microprobe analysis with wavelength-dispersive spectrometry system (EPMA-WDS) methods. The SCM of Radzimowice form the following assemblages: paragenesis I is characterized by langite, posnjakite, brochantite and devilline. These minerals crystallise directly from pH 6.0-7.0 mine waters. Paragenesis II also comprises hydrous copper sulphates (HCS), and in addition contains native copper, cuprite, ferrihydrite and gypsum. Secondary HCS mainly crystallise as products of reactions of sulphate-rich mine waters with native copper and cuprite. The $\mathrm{pH}$ of these waters varies from $\sim 5.0$ to 6.0 . The III paragenesis is dominated by woodwardite, associated with variable amounts of chalcoalumite and amorphous Cu-Al sulphates. Accumulations of woodwardite occur in the zones where Al- and sulphate-rich acid mine waters ( $\mathrm{pH} \sim 2.5-3.0)$ mix with neutral waters $(\mathrm{pH}$ 6.5-7.0). Paragenesis IV is rare, dominated by chrysocolla, coexisting with small amounts of mottramite and goethite. This assemblage formed as a result of mobilization of silica released during decomposition of rock-forming aluminosilicates attacked by acid mine waters.
\end{abstract}

Key words: langite, posnjakite, woodwardite, chalcoalumite, brochantite, Radzimowice.

\section{INTRODUCTION}

Weathering zones of ore beds typically host an unusual wealth of secondary minerals. In the case of deposits containing primary copper minerals (usually sulphides and sulphosalts), the oxidation of these primary species leads to the formation of a variety of SCM. Their qualitative composition depends on chemical factors such as $\mathrm{pH}$, Eh, and the chemical composition of solutions migrating within the particular weathering zones. Research on SCM that control the geochemical behaviour of copper in near-surface parts of the Earth's crust is important because these minerals are responsible for both permanent or seasonal retention of copper and other elements of potential environmental concern in solids. Knowledge of their stability and interdependence provides a basis for understanding and monitoring the processes of copper migration from ore deposits undergoing oxidation.

SCM may also form by oxidation of various technological wastes, including flotation waste or smelting slags. They account for widespread products of the corrosion of metal ele-

\footnotetext{
* Corresponding author, e-mail: siuda@uw.edu.pl
}

Received: March 6, 2013; accepted: June 26, 2013; first published online: August 12, 2013 ments made of copper and its alloys (Dill, 2009; Šatović et al., 2010; Ha et al., 2011; Kierczak et al., 2012). Dissolution and reactions involving SCM from both mine sites and wastes can liberate copper to underground and groundwaters, thus influencing the quality of drinking water. Because of this, particular species of the SCM group are closely studied, both in natural and laboratory conditions (Merkel et al., 2002; Fitzgerald et al., 2006; Taxén et al., 2012).

This paper presents the results of detailed study of recently forming SCM found within abandoned galleries of the polymetallic metal mines in Radzimowice. Attention is paid to the chemical diversity and relation of the SCM to the known crystallochemical solid solutions. Crystallographic and compositional data are reported for the SCM and compared with literature data. We also describe the paragenesis of the SCM assemblages at Radzimowice and evaluate the crystallisation conditions of the recently forming SCM.

\section{GEOLOGICAL SETTING}

The polymetallic Radzimowice deposit is located in the SE part of the Kaczawa Mts. This area includes metamorphosed mudrocks of Lower Paleozoic age classified to the Kaczawa Metamorphic Complex (Fig. 1). They include the Radzimowice slates and Chmielarz slates. Both these rocks are represented by various quartz-sericite-graphite mudrocks, greywackes and 


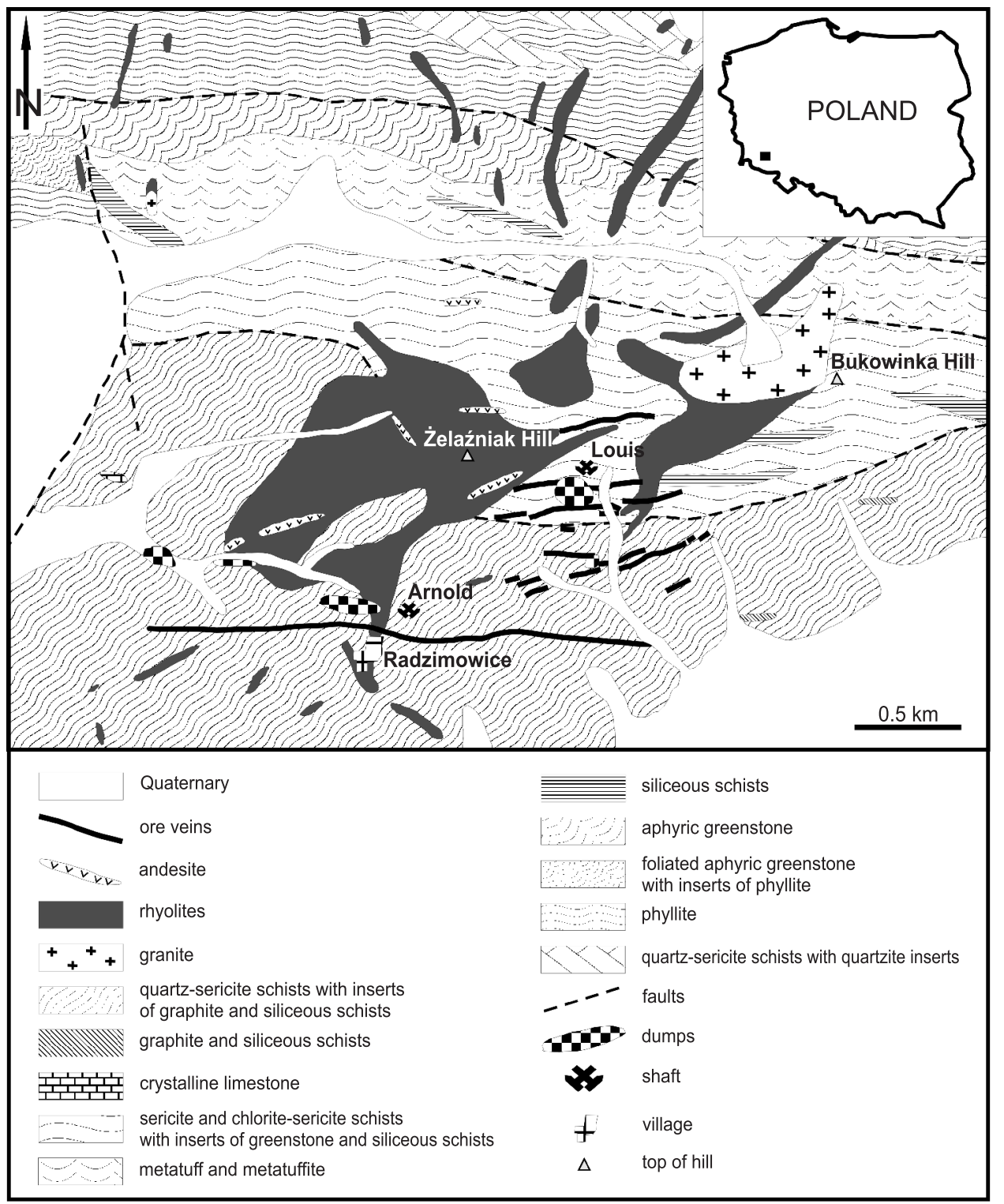

Fig. 1. Geological sketch-map of the Radzimowice area (after Cwojdziński and Kozdrój, 1994)

greenstones, containing insets of crystalline limestone and quartzite (Urbanek and Baranowski, 1986; Haydukiewicz and Urbanek, 1986; Baranowski, 1988; Kozdrój et al., 2001). The metamorphic rocks are cut by younger igneous rocks, mainly rhyolites. The crystallisation age of the rhyolites has been reported as ca. $315 \pm 1 \mathrm{Ma}$ (Machowiak et al., 2008). Within the rhyolites of Żelaźniak and Bukowinka hills, granites are also found (Mikulski, 2003; Machowiak et al., 2008). The rarest igneous rocks are lamprophyres (Manecki, 1962; Mikulski, 2007; Mikulski and Williams, 2010).

The primary ore is mainly present in the form of a dozen or so quartz-sulfide veins, of which 6 were under exploitation (Manecki, 1965; Zimnoch, 1965; Paulo and Salomon, 1974; Mikulski, 2005a, 2007). These crack-type veins cut both the metamorphic rocks of the Kaczawa Metamorphic Complex and the igneous rocks. They run more or less parallel along E-W direction. Dips of the veins are steep (ca. 60-901) and mainly directed to the north. Vein thicknesses vary from a few centi- metres to more than $1 \mathrm{~m}$. The longest vein - "Pocieszenie Górnika" - is ca. 2 km long and $\leq 1.4 \mathrm{~m}$ thick. Barren rocks surrounding the veins are hydrothermally altered and usually contain disseminated ore minerals.

The primary ore vein mineralogy is diverse. The most common primary ore minerals include: pyrite, arsenopyrite, chalcopyrite, sphalerite, galena, marcasite, tetrahedrite, boulangerite, bournonite, meneghinite, gold, bismuth and tellurium minerals associated with barren minerals such as quartz, rhodochrosite and kutnohorite (e.g., Stauffacher, 1916; Manecki, 1965; Zimnoch, 1965; Sylwestrzak and Wołkowicz, 1985; Mikulski, 2005a, b, 2007, 2011; Mikulski and Muszyński, 2012). The ore parageneses formed in several mineralogenic stages, and the age of the ore mineralisation determined by the Re-Os method is $317 \pm 17 \mathrm{Ma}$ (Mikulski et al., 2005a, b; Mikulski, 2007).

By contrast to the hydrothermal parageneses, the weathering zone of the deposit has not previously been fully characterized. The first notes on the presence of secondary species 
within the deposit gave only basic data on a few minerals (native copper, chalcocite, cuprite, hematite, magnetite, cerussite, malachite, pitticite) and limonite (Fiedler, 1863; Traube, 1888; Zimnoch, 1965). The assemblage of secondary phases, including chalcocite, covellite, cuprite, malachite and limonite, from the nearby Bukowinka Hill, was described by Manecki (1965), and details on the occurrence of pseudomalachite in the area are published by Holeczek and Janeczek (1991). Data on hydrous copper sulphates (HCS), iron arsenates, vanadates and iron oxyhydroxides was reported by Siuda (2001, 2004), Siuda and Kruszewski (2005) and Parafiniuk and Siuda (2006).

\section{METHODS}

Powder X-Ray Diffraction (PXRD) was the most important method used for mineral identification. PXRD analyses were done on a Bruker axs D8 Advance diffractometer in the X-Ray Diffraction Laboratory, Institute of Geological Sciences, Polish Academy of Sciences, Warszawa. The diffractometer was equipped with a superfast LPS (linear position-sensitive) Vcntec-1 detector. The radiation was CoK $\alpha$, filtered but not monochromatized. Unit-cell parameters and crystallite size of SCM were refined using the Rietveld method (Rietveld, 1967) in the Topas software ( $v$ 4.0). For chrysocolla (structure unknown), hkl values were assigned as the starting refinement parameters. The software version used was not compatible with PSD (position sensitive detector), and the diffractometer has a radial soller instead of an anti-scatter (i.e., receiving) slit to increase the low-angle intensity yield. Thus, the diffractometer had to be adjusted prior to exact refinements. For this purpose $\mathrm{LaB}_{6}$ and Si standards (NIST SRM 660a and 640c, respectively) were used. The "receiving slit" parameter was replaced by an additional convolution (Lorentzian, constant $2 \theta$ dependence). Its value was refined by fixing structural parameters of the standards and then used as fixed for SCM refinements (D. Bish, pers. comm., 2013 via Rietveld Mailing List). The chemical compositions of minerals were analysed at the Inter-Institute Analytical Complex for Minerals and Synthetic Substances, University of Warsaw, on a Cameca SX-100 electron microprobe operating in the WDS. $\mathrm{Fe}_{2} \mathrm{O}_{3}(\mathrm{Fe})$, chalcopyrite $(\mathrm{Cu})$, galena $(\mathrm{Pb})$, orthoclase $(\mathrm{Al})$, diopside $(\mathrm{Ca}, \mathrm{Si}), \mathrm{ZnS}(\mathrm{Zn})$, $\mathrm{Bi}_{2} \mathrm{Te}_{3}(\mathrm{Bi})$, barite (S), GaAs (As), apatite $(\mathrm{P})$, and vanadium metal $(\mathrm{V})$ were used as reference materials. The accelerating voltage was $15 \mathrm{kV}$, the beam diameter $10 \mu \mathrm{m}$. IR absorption spectra were recorded within a Nicolet Magna 550 spectrometer, from 4000 to $400 \mathrm{~cm}^{-1}$, using $\mathrm{KBr}$ pellets (Faculty of Chemistry, University of Warsaw).

\section{SECONDARY COPPER MINERALS}

$$
\text { BROCHANTITE } \mathrm{Cu}_{4}\left(\mathrm{SO}_{4}\right)(\mathrm{OH})_{6}
$$

Brochantite is found as emerald-green crusts on the surface of rhyolitic rocks which contain weathered chalcopyrite. Brochantite aggregates are composed of small $(<1 \mathrm{~mm})$ tabular crystals. These crystals very often form typical, comb-like intergrowths (Fig. 2A), associated with langite, posnjakite, malachite and small amounts of devilline. The mineral is also present within accumulations of $\mathrm{Fe}$-oxyhydroxides comprising mainly ferrihydrite. In this case brochantite is usually associated with other copper sulphate minerals, native copper, cuprite, and small amounts of chalcoalumite, malachite, and gypsum.
Refined unit cell parameters of the Radzimowice brochantite are in good agreement with those previously reported for the mineral (Table 1), especially with the parameters reported for brochantite from the Gelnica deposit in Slovakia (Sejkora et al., 2001), the Krásno ore district in Czech Republic (Sejkora et al., 2006), and also for the material analysed by Mills et al. (2010). No evidence of the 2M2 polytype, reported from Pierre Plate Mine, Vizille, France (Crichton and Müller, 2008), was found.

The chemical analysis of brochantite (Table 1) bears an error due to partial sample evaporation, giving an excess of $\mathrm{H}$ atoms. Thus, the correct empirical cannot be given. For the same reason, the empirical formulas of further hydrated species have $\mathrm{H}_{2} \mathrm{O}$ molecules artificially added. The specific feature of the Radzimowice brochantite is an iron admixture, from 0.01 to 0.18 apfu. It follows the $\mathrm{Fe}^{2+}$ for $\mathrm{Cu}^{2+}$ substitution trend, as reported, for instance by Fitzgerald et al. (2006). The unit cell parameters of the brochantite do not seem to be influenced by the minor $\mathrm{Fe}^{2+}$ substitution.

\section{CHALCOALUMITE CuAl ${ }_{4}\left(\mathrm{SO}_{4}\right)(\mathrm{OH})_{12} \cdot 3 \mathrm{H}_{2} \mathrm{O}$}

The relatively rare mineral chalcoalumite forms small stalactites, stalagmites, and draperies, $\leq 5 \mathrm{~cm}$ in size, of light to deep blue colour (Fig. 3A). They comprise ball-like aggregates, $\leq 200 \mu \mathrm{m}$ in size, forming botryoidal segregations. Chalcoalumite aggregates may also fill spaces in stalactitic ferrihydrite (Fig. 4A). In this case, chalcoalumite is associated with small amounts of brochantite, posnjakite and langite. Traces of chalcoalumite are known to crystallise within woodwardite accumulations. When in the natural humidity state, chalcoalumite aggregates are soft and plastic. After drying the mineral becomes brittle and friable.

The chalcoalumite always gives broad PXRD reflections. The $d$ value of the $(200)$ basal reflection is in the range of 8.54-8.58 A. The clearly visible (400) reflection of the (h00) planes at $d \approx 4.27$ confirms the presence of chalcoalumite. The calculated crystal size (Lorentzian) is 20.1(9) nanometres. Unit cell parameters are close to those reported previously; nevertheless, it is difficult to make comparisons due to the small amount of data available for the species (Table 2).

Analysis of chalcoalumite from Radzimowice showed its heterogeneous chemical composition due to the presence of minute inclusions of strongly hydrated amorphous Cu-Al sulphate. Low analytical totals are due to the porous nature of chalcoalumite aggregates and low stability of this phase under vacuum conditions. The obtained mean oxide contents (wt.\%, $n=5)$ are: $8.39 \mathrm{SO}_{3}, 43.97 \mathrm{Al}_{2} \mathrm{O}_{3}$ and $7.78 \mathrm{CuO}$.

\section{CHRYSOCOLLA $\left(\mathrm{Cu}, \mathrm{Al}_{2} \mathrm{H}_{2} \mathrm{SI}_{2} \mathrm{O}_{5}(\mathrm{OH})_{4} \cdot \mathrm{nH}_{2} \mathrm{O}\right.$}

This mineral appears only at the first level of the mine, located $30 \mathrm{~m}$ below the ground. Chrysocolla forms thin encrustations, up to few millimetres thick, covering surfaces of small joints cutting rhyolites. It is associated with goethite and small amounts of mottramite.

The copper content of the Radzimowice chrysocolla varies from 44.25 to 46.73 wt. $\% \mathrm{CuO}$, while the corresponding values for silicon are in the range of 35.55-38.12 wt. \% $\mathrm{SiO}_{2}$ (Table 3). The mineral analysed is relatively pure; the minor admixtures may include some iron (up to 0.26 wt. $\% \mathrm{Fe}_{2} \mathrm{O}_{3}$ ), zinc (up to 0.31 wt. $\% \mathrm{ZnO}$ ), calcium ( 0.12 to $0.23 \mathrm{wt} . \% \mathrm{CaO}$ ), phosphorus (up to 0.12 wt. $\% \mathrm{P}_{2} \mathrm{O}_{5}$ ) and sulphur (up to 0.12 wt. $\% \mathrm{SO}_{3}$ ). $\mathrm{Al}$, $\mathrm{Mn}, \mathrm{Pb}, \mathrm{Bi}, \mathrm{As}$ and $\mathrm{V}$ were not detected. The empirical formula 

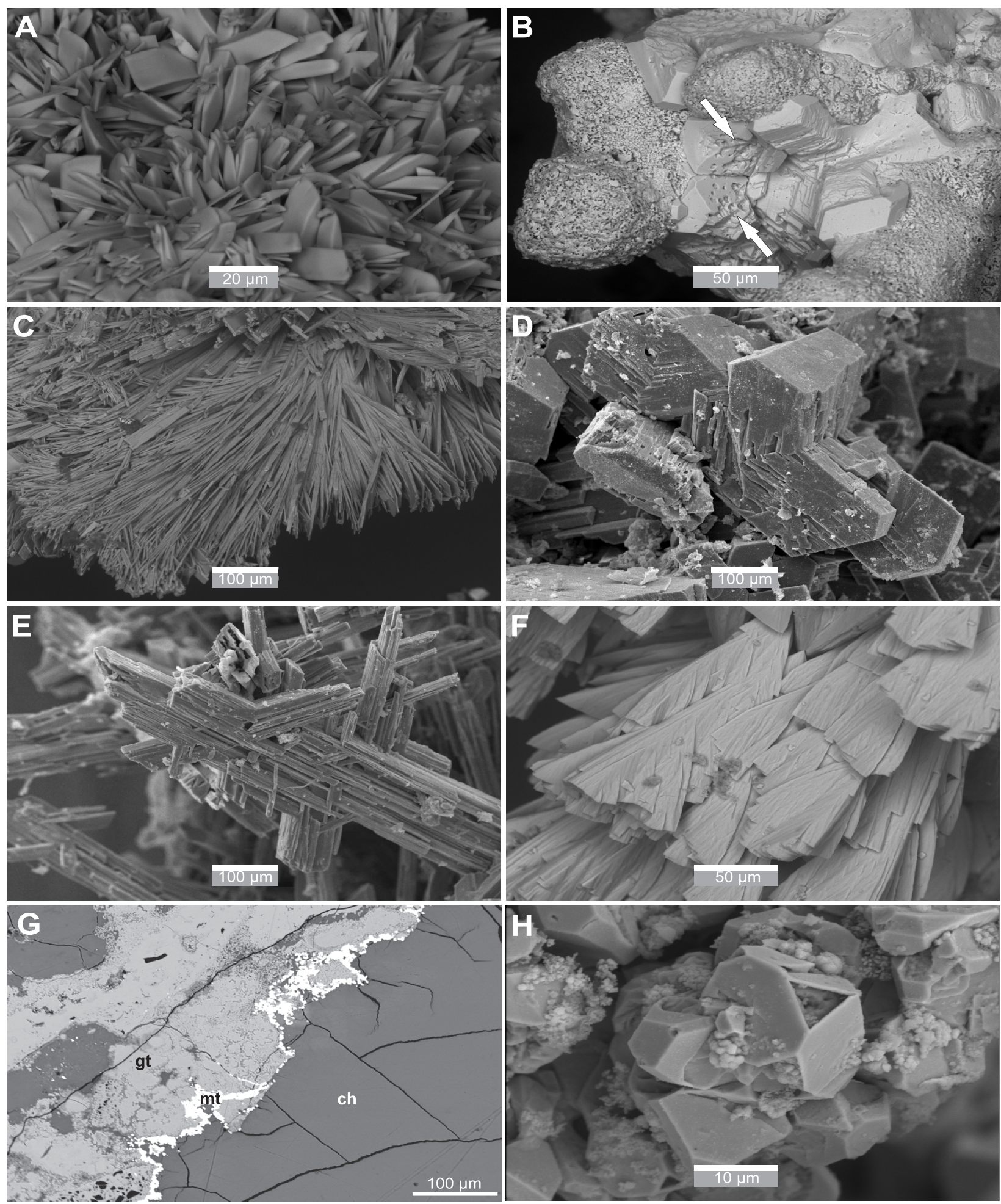

Fig. 2. Secondary copper minerals from the abandoned mine in Radzimowice (SEM images)

A - tabular crystals of brochantite, B - cuprite growing on native copper (arrows indicate traces of dissolution), C - radial aggregate of devilline, D - langite twin parallel to $\{110\}, \mathbf{E}$ - aggregates of elongated crystals of langite, $\mathbf{F}$ - feathery aggregates of posnjakite replacing langite, $\mathbf{G}$ - back-scattered electrons image of mottramite $(\mathrm{mt})$ accumulations at the border of chrysocolla (ch) and goethite (gt), $\mathbf{H}$ - crystals of native copper 
Ta ble 1

Chemical composition (wt. \%) and crystallographic data for brochantite from Radzimowice

\begin{tabular}{|l|c|c|c|c|c|c|c|c|}
\hline $\begin{array}{c}\text { Number } \\
\text { of } \\
\text { analyses }\end{array}$ & 1 & 2 & 3 & 4 & 5 & 6 & 7 & 8 \\
\hline $\mathrm{SO}_{3}$ & 16.32 & 14.04 & 14.21 & 15.72 & 14.69 & 14.34 & 14.31 & 15.26 \\
\hline $\mathrm{P}_{2} \mathrm{O}_{5}$ & 0.09 & 0.00 & 0.00 & 0.00 & 0.00 & 0.00 & 0.00 & 0.00 \\
\hline $\mathrm{Fe}_{2} \mathrm{O}_{3}$ & 0.39 & 1.02 & 3.27 & 0.24 & 0.57 & 0.27 & 0.30 & 0.33 \\
\hline $\mathrm{Al}_{2} \mathrm{O}_{3}$ & 0.10 & 0.00 & 0.00 & 0.00 & 0.00 & 0.00 & 0.00 & 0.00 \\
\hline $\mathrm{CuO}$ & 72.11 & 72.30 & 67.98 & 70.88 & 67.24 & 67.47 & 67.42 & 68.18 \\
\hline$\Sigma$ & 89.01 & 87.36 & 85.46 & 86.84 & 82.50 & 82.08 & 82.03 & 83.77 \\
\hline $\mathrm{H}_{2} \mathrm{O}^{1)}$ & 10.99 & 12.64 & 14.54 & 13.16 & 17.50 & 17.92 & 17.97 & 16.23 \\
\hline & & & & & & & & \\
\hline
\end{tabular}

$$
\text { apfu (base: } \mathrm{Cu}+\mathrm{Fe}+\mathrm{Al}=4 \text { ) }
$$

\begin{tabular}{|l|l|l|l|l|l|l|l|l|}
\hline $\mathrm{S}$ & 0.89 & 0.76 & 0.79 & 0.88 & 0.86 & 0.84 & 0.84 & 0.89 \\
\hline $\mathrm{Fe}^{2+}$ & 0.02 & 0.06 & 0.18 & 0.01 & 0.03 & 0.02 & 0.02 & 0.02 \\
\hline $\mathrm{Cu}$ & 3.97 & 3.94 & 3.82 & 3.99 & 3.97 & 3.98 & 3.98 & 3.98 \\
\hline $\mathrm{Al}$ & 0.01 & & & & & & & \\
\hline $\mathrm{P}$ & 0.01 & & & & & & & \\
\hline $\mathrm{S}$ & 0.89 & 0.76 & 0.79 & 0.88 & 0.86 & 0.84 & 0.84 & 0.89 \\
\hline
\end{tabular}

\begin{tabular}{|c|c|c|c|c|c|}
\hline S & 0.89 & 0.88 & 0.84 & 0.84 & \\
\hline \multicolumn{6}{|c|}{ unit cell parameters (with refinement statistics ${ }^{2}$ ) } \\
\hline Sample & & & & broch & \\
\hline $\mathrm{a}[\AA]$ & & & & 13.125 & \\
\hline $\mathrm{b}[\AA]$ & & & & 9.858 & \\
\hline$c[\AA]$ & & & & 6.019 & \\
\hline$B\left[^{\circ}\right]$ & & & & 103.32( & \\
\hline Rwp & & & & 14.09 & \\
\hline GoF & & & & 4.96 & \\
\hline DW & & & & 0.20 & \\
\hline
\end{tabular}

1) calculated as $100-\Sigma ;{ }^{2}$ Rwp - residual weighted pattern; GoF - goodness of fit (i.e., $\chi^{2}$ ); DW - Durbin-Watson statistics (also known as $d_{D W}$ ); apfu - atoms per formula unit

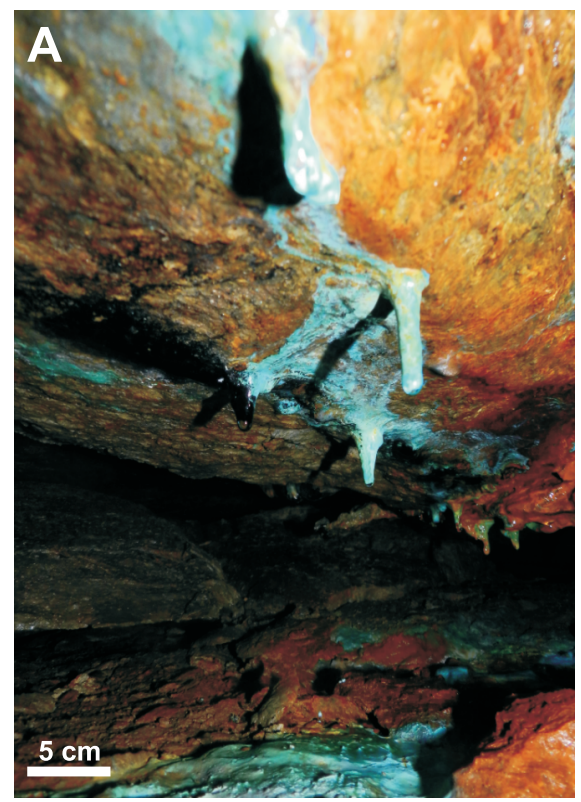

of the chrysocolla $(n=12)$ may be written as $\left(\mathrm{Cu}_{1.87} \mathrm{Ca}_{0.01}\right)_{\Sigma 1.88} \mathrm{H}_{1.88} \mathrm{Si}_{1.99} \mathrm{O}_{5}(\mathrm{OH})_{4} \cdot 0.92 \mathrm{H}_{2} \mathrm{O}$.

The use of the very precise Vcntec-1 detector allowed us to obtain high-quality PXRD data for chrysocolla. On the diffractogram, broad but clear reflections of chrysocolla and goethite can be seen. The Scherrer widening due to small crystallite size, refined to be 9.6(1) for chrysocolla and 13.6(4) for goethite, is evident. It is notable that the statistical quality all the refinement trials performed is very good, i.e., with Rwp values always below 2.00 (Table 3).

\section{CUPRITE $\mathrm{Cu}_{2} \mathrm{O}$}

In old adits of the mine, cuprite occurs within stalagmites of ferrihydrite, as finely crystalline, $\leq 1 \mathrm{~cm}$ aggregates of dark red-brown colour (Fig. 4B). Cuprite very often grows on the surface of dendritic copper (Fig. 2B). Individual crystals are $\leq 50 \mu \mathrm{m}$ in size. A combination of cube and trisoctahedron faces is observed. Cubic faces very often reveal characteristic traces of leaching, indicating a seasonal dissolution of the mineral (Fig. 2B). Cuprite may also be associated with minor amounts of brochantite, langite, posnjakite, amorphous Cu-Al sulphates, chalcoalumite, malachite and gypsum.

The refined cuprite unit cell parameters (Table 4) correspond well to the published data (Sejkora et al., 2006).

The chemical composition of cuprite is close to the theoretical one (Table 4). Small amounts of iron in cuprite from Radzimowice may come from micro-inclusions of Fe oxyhydroxides. The

Fig. 3. Cu-Al sulphates from the abandoned mine in Radzimowice

A - stalactites of chalcoalumite, B - accumulations of woodwardite on the walls of an old shaft,

C - blue accumulations of woodwardite connected with a zone of mixing of acid mine waters with neutral waters 

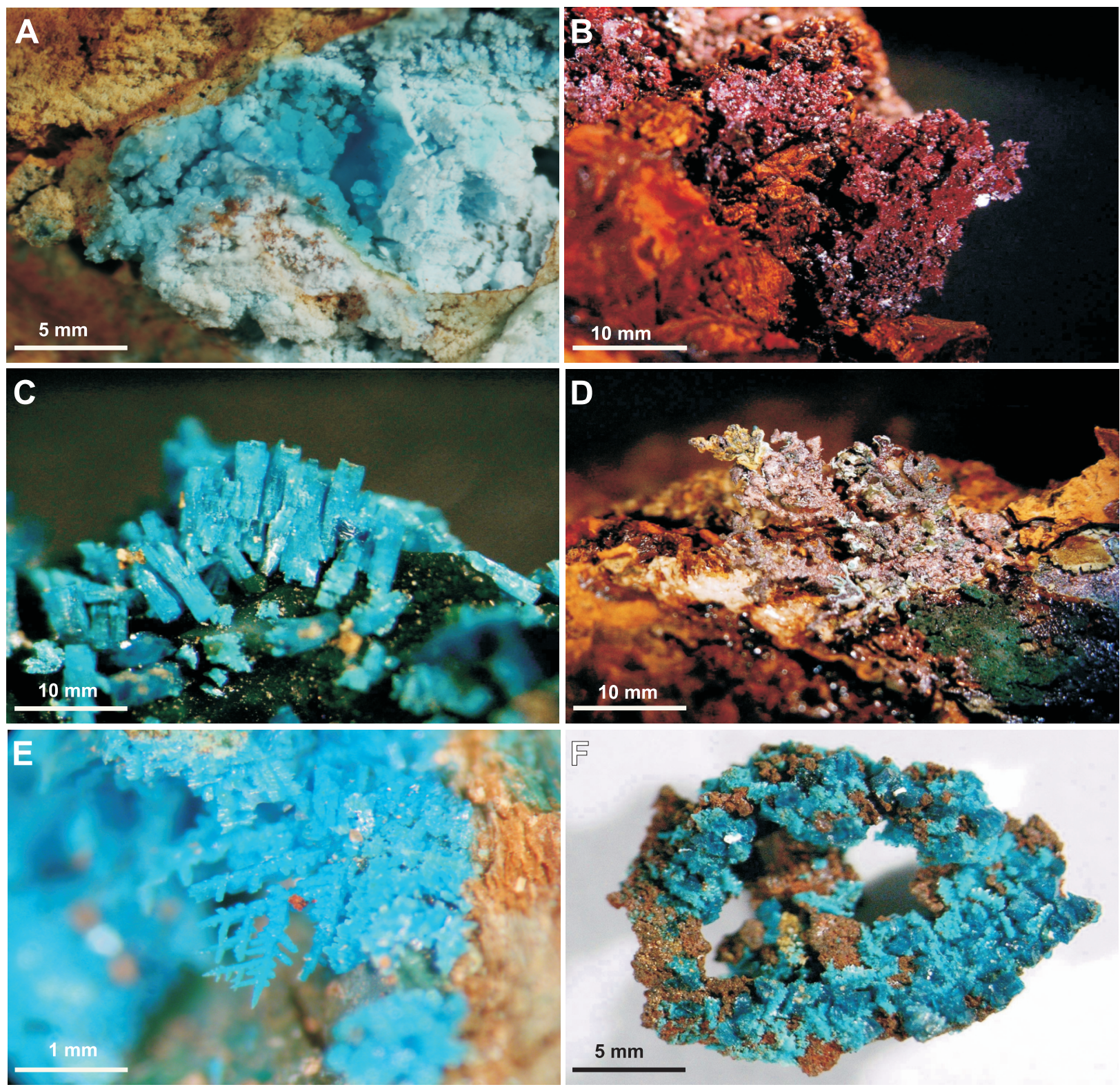

Fig. 4. Formation of various secondary copper minerals from Radzimowice

A - blue aggregates of chalcoalumite inside stalactite of ferrihydrite, B - accumulation of cuprite in ferrihydrite, C - aggregate of langite crystals, $\mathbf{D}$ - dendrites of native copper in ferrihydrite, $\mathbf{E}$ - dendritic crystals of posnjakite, $\mathbf{F}$ - posnjakite (light blue) and langite (deep blue) replacing aggregates of native copper and cuprite

quantitative chemical analysis of cuprite gives the following empirical formula $(n=10): \mathrm{Cu}_{2.00} \mathrm{Fe}_{0.02} \mathrm{O}$.

\section{DEVILLINE $\mathrm{CaCu}_{4}\left(\mathrm{SO}_{4}\right)_{2}(\mathrm{OH})_{6} \cdot 3 \mathrm{H}_{2} \mathrm{O}$}

Devilline is the most rarely observed of the basic $\mathrm{Cu}$ sulphate minerals at Radzimowice. It forms tiny aggregates, $\leq 5 \mathrm{~mm}$ in diameter, comprising thin-bladed crystals up to $2 \mathrm{~mm}$ in length. That are characterized by a pearly luster and greenish colour. The aggregates may be ball-like or radial (Fig. 2C). They are found within open spaces of the ferrihydrite stalactites or covering the surface of mineralised rhyolites that contain ore minerals undergoing weathering to brochantite, langite, posnjakite and malachite. Representative EMPA (electron microprobe analysis) of devilline are given in Table 5 . The mineral contains minor admixtures of silica (up to $1.03 \mathrm{wt} . \%$ ) and alumina (up to $0.91 \mathrm{wt} . \%$ ). The empirical formula $(n=10)$ is: $\mathrm{Ca}_{1.00}\left(\mathrm{Cu}_{3.96} \mathrm{Al}_{0.04}\right)_{\Sigma 4.00}\left[\left(\mathrm{SO}_{4}\right)_{1.99}\left(\mathrm{SiO}_{4}\right)_{0.05}\right]_{\Sigma 2.04}(\mathrm{OH})_{6} \cdot 0.61 \mathrm{H}_{2} \mathrm{O}$.

The minor $\mathrm{Al}$ and $\mathrm{Si}$ substitution in the Radzimowice devilline does not seem to influence the unit cell parameters much (Table 5). The obtained values are comparable to those reported for chemically pure devilline by Ondruš et al. (1997) and also for the mineral as recorded in the RRUFF database (Downs, 2006). 
Table 2

Crystallographic data for chalcoalumite from Radzimowice

\begin{tabular}{|l|c|c|}
\hline \multicolumn{3}{|c|}{$\begin{array}{c}\text { Unit cell parameters } \\
\text { (with refinement results) }\end{array}$} \\
\hline Sample & $35 A$ & $199 \mathrm{~B}$ \\
\hline $\mathrm{a}[\AA]$ & $17.11(2)$ & $17.03(5)$ \\
\hline $\mathrm{b}[\AA]$ & $8.93(2)$ & $8.97(2)$ \\
\hline $\mathrm{c}[\AA]$ & $10.19(2)$ & $10.19(1)$ \\
\hline$\left.\alpha{ }^{\circ}\right]$ & $95.1(2)$ & $94.8(2)$ \\
\hline Rwp & 2.28 & 3.22 \\
\hline GoF & 1.33 & 1.15 \\
\hline $\mathrm{DW}$ & 1.33 & 1.74 \\
\hline
\end{tabular}

1) unit cell parameters for coexisting woodwardite-3R for sample 35A and 199B: a $3.021(2)$ and 3.078(2), c - 25.48(3) and 25.51(2), respectively; for other explanations see Table 1

LANGITE $\mathrm{Cu}_{4}\left(\mathrm{SO}_{4}\right)(\mathrm{OH}) 6 \cdot 2 \mathrm{H}_{2} \mathrm{O}$

In the abandoned mine galleries langite forms two types of aggregates. The first type grows on the surface of rocks con- taining disseminated chalcopyrite. Together with posnjakite, devilline, brochantite, and malachite, the langite aggregates cover parts of sidewalls, over areas of a few square metres where it crystallises directly from the mine drainage waters. The second type of langite aggregate occurs within stalactites and stalagmites of $\mathrm{Fe}$ oxyhydroxides. This type of langite coexists with aforementioned HCS, chalcoalumite, and small amounts of malachite, gypsum, and amorphous $\mathrm{Cu}-\mathrm{Al}$ sulphates. In the second-type aggregates, signs of the replacement of copper-cuprite intergrowths by langite and posnjakite are very often observed. Small amounts of langite may also be associated with woodwardite.

The langite crystals are characterized by sky-blue colour and glassy luster (Fig. 4C). They are $\leq 2 \mathrm{~mm}$ in size. Typically, crystals are combinations of monoclinic prisms and pinacoids, with the $\{001\}$ pinacoid dominating and langite crystal faces showing clear dissolution features. Twins and multi-twins on $\{110\}$, specific for langite, are also very often observed (Fig. 2D). They form characteristic star-like intergrowths, as reported from other mineralogical localities (Williams, 1964; Pulou et al., 1978).

Langite was identified by X-ray powder diffraction data at a number of samples (Table 6). The data obtained does not differ much from PXRD characteristics of langite from other localities (Řídkošil and Povondra, 1982). Also, the unit cell parameters are in good agreement with the ones reported by the RRUFF database (Downs, 2006) and by previous researchers, namely Gentsch and Weber (1984) and Galy et al. (1984).

Chemical composition (wt.\%) and crystallographic data for chrysocolla from Radzimowice

\begin{tabular}{|c|c|c|c|c|c|c|c|c|c|c|c|c|}
\hline $\begin{array}{c}\text { Number } \\
\text { of } \\
\text { analyse }\end{array}$ & 1 & 2 & 3 & 4 & 5 & 6 & 7 & 8 & 9 & 10 & 11 & 12 \\
\hline $\mathrm{P}_{2} \mathrm{O}_{5}$ & 0.1 & 0.0 & 0.12 & 0.1 & 0.06 & 0 & 0.09 & 0.06 & 0.1 & 0.0 & 0.1 & 0.08 \\
\hline $\mathrm{SO}_{3}$ & 0.08 & 0.08 & 0.07 & 0.0 & 0.0 & 0.06 & 0.11 & 0.08 & 0.12 & 0.07 & 0.11 & 0.09 \\
\hline $\mathrm{SiO}_{2}$ & 36.6 & 36.55 & 37.01 & 36.96 & 36.8 & 37.09 & 37.69 & 37.28 & 37.48 & 37.93 & 38.12 & 35.55 \\
\hline $\mathrm{Fe}_{2} \mathrm{O}_{3}$ & 0.0 & 0.0 & 0.0 & 0.0 & 0.0 & 0.0 & 0.0 & 0.0 & 0.0 & 0.0 & 0.16 & 0.26 \\
\hline $\mathrm{Al}_{2} \mathrm{O}_{3}$ & 0.0 & 0.0 & 0.0 & 0.0 & 0.0 & 0.0 & 0.0 & 0.0 & 0.0 & 0.0 & 0.0 & 0.0 \\
\hline $\mathrm{ZnO}$ & 0.0 & 0.31 & 0.0 & 0.0 & 0.21 & 0.0 & 0.0 & 0.18 & 0.0 & 0.25 & 0.21 & 0.17 \\
\hline $\mathrm{CuO}$ & 46.39 & 46.36 & 46.09 & 46.37 & 46.05 & 46.23 & 45.46 & 45.82 & 45.74 & 45.25 & 44.96 & 46.73 \\
\hline $\mathrm{CaO}$ & 0.2 & 0.2 & 0.17 & 0.12 & 0.16 & 0.16 & 0.14 & 0.18 & 0.14 & 0.12 & 0.2 & 0.23 \\
\hline$\Sigma$ & 83.37 & 83.5 & 83.46 & 83.55 & 83.28 & 83.54 & 83.49 & 83.6 & 83.58 & 83.62 & 83.86 & 83.11 \\
\hline $\mathrm{H}_{2} \mathrm{O}^{1)}$ & 16.63 & 16.5 & 16.54 & 16.45 & 16.72 & 16.46 & 16.51 & 16.4 & 16.42 & 16.38 & 16.14 & 16.89 \\
\hline \multicolumn{13}{|c|}{ apfu (base: $\mathrm{Si}+\mathrm{P}+\mathrm{S}=2$ ) } \\
\hline $\mathrm{P}$ & & & 0.01 & & & & & & & & & \\
\hline $\mathrm{Si}$ & 1.99 & 2.00 & 1.99 & 2.00 & 2.00 & 2.00 & 1.99 & 1.99 & 1.99 & 2.00 & 1.99 & 1.99 \\
\hline $\mathrm{Fe}$ & & & & & & & & & & & 0.01 & 0.01 \\
\hline $\mathrm{Zn}$ & & 0.01 & & & 0.01 & & & 0.01 & & 0.01 & 0.01 & 0.01 \\
\hline $\mathrm{Cu}$ & 1.91 & 1.91 & 1.87 & 1.89 & 1.89 & 1.88 & 1.81 & 1.85 & 1.83 & 1.80 & 1.77 & 1.98 \\
\hline $\mathrm{Ca}$ & 0.01 & 0.01 & 0.01 & 0.01 & 0.01 & 0.01 & 0.01 & 0.01 & 0.01 & 0.01 & 0.01 & 0.01 \\
\hline \multicolumn{13}{|c|}{ unit cell parameters (with refinement statistics) } \\
\hline$a[\AA]]$ & \multicolumn{12}{|c|}{$5.81(3)$} \\
\hline $\mathrm{b}[\AA]]$ & \multicolumn{12}{|c|}{$17.51(5)$} \\
\hline$c[\AA]$ & \multicolumn{12}{|c|}{$8.02(3)$} \\
\hline Rwp & \multicolumn{12}{|c|}{1.39} \\
\hline GoF & \multicolumn{12}{|c|}{1.10} \\
\hline DW & \multicolumn{12}{|c|}{1.78} \\
\hline
\end{tabular}

\footnotetext{
1) calculated as $100-\Sigma$; for other explanations see Table 1
} 
Chemical composition (wt.\%) and crystallographic data for cuprite from Radzimowice

\begin{tabular}{|c|c|c|c|c|c|c|c|c|c|c|}
\hline $\begin{array}{c}\text { Number } \\
\text { of } \\
\text { analyse }\end{array}$ & 1 & 2 & 3 & 4 & 5 & 6 & 7 & 8 & 9 & 10 \\
\hline $\mathrm{Cu}_{2} \mathrm{O}$ & 99.05 & 98.58 & 99.17 & 99.31 & 99.23 & 99.11 & 98.70 & 99.47 & 99.31 & 99.30 \\
\hline $\mathrm{Fe}_{2} \mathrm{O}_{3}$ & 1.52 & 1.26 & 1.34 & 0.98 & 1.26 & 1.13 & 1.84 & 0.81 & 0.99 & 0.99 \\
\hline$\Sigma$ & 100.57 & 99.84 & 100.51 & 100.29 & 100.49 & 100.24 & 100.54 & 100.28 & 100.30 & 100.29 \\
\hline \multicolumn{11}{|c|}{ apfu (base: $O=1$ ) } \\
\hline $\mathrm{Cu}$ & 1.96 & 1.97 & 1.96 & 1.97 & 1.97 & 1.97 & 1.95 & 1.98 & 1.97 & 1.97 \\
\hline $\mathrm{Fe}$ & 0.01 & 0.01 & 0.01 & 0.01 & 0.01 & 0.01 & 0.02 & 0.01 & 0.01 & 0.01 \\
\hline \multicolumn{11}{|c|}{ unit cell parameters (with refinement statistics) } \\
\hline$a[\AA]$ & \multicolumn{10}{|c|}{$4.268(1)$} \\
\hline Rwp & \multicolumn{10}{|c|}{12.04} \\
\hline GoF & \multicolumn{10}{|c|}{1.17} \\
\hline DW & \multicolumn{10}{|c|}{1.48} \\
\hline
\end{tabular}

For explanation see Table 1

Table 5

Chemical composition (wt.\%) and crystallographic data for devilline from Radzimowice

\begin{tabular}{|c|c|c|c|c|c|c|c|c|c|c|}
\hline $\begin{array}{c}\text { Number } \\
\text { of } \\
\text { analyse }\end{array}$ & 1 & 2 & 3 & 4 & 5 & 6 & 7 & 8 & 9 & 10 \\
\hline $\mathrm{SO}_{3}$ & 24.25 & 23.63 & 23.64 & 24.66 & 25.36 & 24.44 & 24.46 & 24.49 & 24.49 & 23.99 \\
\hline $\mathrm{SiO}_{2}$ & 0.68 & 1.03 & 0.97 & 0.83 & 0.59 & 0.21 & 0.00 & 0.21 & 0.00 & 0.10 \\
\hline $\mathrm{Al}_{2} \mathrm{O}_{3}$ & 0.38 & 0.91 & 0.47 & 0.40 & 0.38 & 0.22 & 0.19 & 0.08 & 0.00 & 0.18 \\
\hline $\mathrm{CuO}$ & 48.11 & 47.92 & 48.36 & 48.06 & 47.78 & 48.55 & 48.39 & 48.48 & 48.70 & 48.47 \\
\hline $\mathrm{CaO}$ & 8.25 & 8.39 & 8.29 & 8.18 & 7.65 & 8.52 & 8.88 & 9.17 & 8.72 & 9.46 \\
\hline$\Sigma$ & 81.67 & 81.88 & 81.73 & 82.13 & 81.76 & 81.94 & 81.92 & 82.43 & 81.91 & 82.20 \\
\hline $\mathrm{H}_{2} \mathrm{O}^{1)}$ & 18.33 & 18.12 & 18.27 & 17.87 & 18.24 & 18.06 & 18.08 & 17.57 & 18.09 & 17.80 \\
\hline \multicolumn{11}{|c|}{ apfu (base: $\mathrm{Cu}+\mathrm{Ca}+\mathrm{Al}=5$ ) } \\
\hline S & 1.99 & 1.92 & 1.93 & 2.03 & 2.13 & 1.99 & 1.98 & 1.98 & 1.99 & 1.92 \\
\hline $\mathrm{Si}$ & 0.07 & 0.11 & 0.11 & 0.09 & 0.07 & 0.02 & 0.00 & 0.02 & 0.00 & 0.01 \\
\hline $\mathrm{Al}$ & 0.05 & 0.12 & 0.06 & 0.05 & 0.05 & 0.03 & 0.02 & 0.01 & 0.00 & 0.02 \\
\hline $\mathrm{Cu}$ & 3.98 & 3.91 & 3.97 & 3.99 & 4.03 & 3.98 & 3.95 & 3.93 & 3.99 & 3.90 \\
\hline $\mathrm{Ca}$ & 0.97 & 0.97 & 0.97 & 0.96 & 0.92 & 0.99 & 1.03 & 1.06 & 1.01 & 1.08 \\
\hline \multicolumn{11}{|c|}{ unit cell parameters (with refinement statistics) } \\
\hline sample & $\operatorname{dev} 1$ & \multicolumn{9}{|c|}{ 199B } \\
\hline$a[\AA]$ & $20.836(4)$ & \multicolumn{9}{|c|}{$20.84(1)$} \\
\hline $\mathrm{b}[\AA]$ & $6.104(2)$ & \multicolumn{9}{|c|}{$6.136(3)$} \\
\hline$c[\AA]$ & $22.177(5)$ & \multicolumn{9}{|c|}{$22.19(1)$} \\
\hline$B\left[^{\circ}\right]$ & $102.66(2)$ & \multicolumn{9}{|c|}{$102.80(5)$} \\
\hline Rwp & 7.59 & \multicolumn{9}{|c|}{3.22} \\
\hline GoF & 1.12 & \multicolumn{9}{|c|}{1.15} \\
\hline DW & 0.79 & \multicolumn{9}{|c|}{1.74} \\
\hline
\end{tabular}

For explanations see Tables 1 and 3

Replacement of langite by posnjakite is commonly manifested in our samples, with gradual crystal morphology change being observed. PXRD patterns of typical langite crystals reveal no admixtures of other species. In conjunction with its morphology change, i.e., distinct elongation and division into smaller individuals (Fig. 2E), increasing numbers of reflections specific to posnjakite are noticed. Feathery aggregates (Fig. 2F) are exclusively made up of posnjakite.

Quantitative chemical analyses obtained for langite correspond well to its ideal composition (Table 6). Cu and S are the dominant elements. Small amounts of alumina (up to 
Chemical composition (wt.\%) and crystallographic data for langite from Radzimowice

\begin{tabular}{|c|c|c|c|c|c|c|c|c|c|c|}
\hline $\begin{array}{c}\text { Number } \\
\text { of } \\
\text { analyse }\end{array}$ & 1 & 2 & 3 & 4 & 5 & 6 & 7 & 8 & 9 & 10 \\
\hline $\mathrm{SO}_{3}$ & 16.77 & 17.28 & 16.18 & 15.90 & 16.16 & 16.31 & 16.29 & 16.27 & 16.64 & 16.63 \\
\hline $\mathrm{SiO}_{2}$ & 0.00 & 1.23 & 1.08 & 0.89 & 0.42 & 0.00 & 0.00 & 0.06 & 0.00 & 0.00 \\
\hline $\mathrm{Al}_{2} \mathrm{O}_{3}$ & 0.00 & 0.65 & 1.79 & 0.60 & 0.42 & 0.00 & 0.56 & 0.10 & 0.00 & 0.00 \\
\hline $\mathrm{CuO}$ & 64.70 & 62.83 & 63.67 & 64.35 & 64.43 & 65.60 & 64.79 & 65.71 & 65.26 & 65.26 \\
\hline$\Sigma$ & 81.47 & 81.99 & 82.72 & 81.74 & 81.43 & 81.91 & 81.64 & 82.14 & 81.90 & 81.89 \\
\hline $\mathrm{H}_{2} \mathrm{O}^{1)}$ & 18.53 & 18.01 & 17.28 & 18.26 & 18.57 & 18.09 & 18.36 & 17.86 & 18.10 & 18.11 \\
\hline \multicolumn{11}{|c|}{ apfu (base: $\mathrm{Cu}+\mathrm{Al}=4$ ) } \\
\hline$S$ & 1.03 & 1.08 & 0.97 & 0.97 & 0.99 & 0.99 & 0.99 & 0.98 & 1.01 & 1.01 \\
\hline $\mathrm{Si}$ & & 0.10 & 0.09 & 0.07 & 0.03 & & & 0.01 & & \\
\hline $\mathrm{Al}$ & & 0.06 & 0.17 & 0.06 & 0.04 & & 0.05 & 0.01 & & \\
\hline $\mathrm{Cu}$ & 4.00 & 3.94 & 3.83 & 3.94 & 3.96 & 4.00 & 3.95 & 3.99 & 4.00 & 4.00 \\
\hline \multicolumn{11}{|c|}{ unit cell parameters (with refinement statistics) } \\
\hline Sample & lang 1 & lang 2 & lang 3 & \multicolumn{7}{|c|}{ lang 4} \\
\hline$a[\AA]$ & $7.1278(7)$ & $7.119(6)$ & $7.130(8)$ & \multicolumn{7}{|c|}{$7.122(1)$} \\
\hline $\mathrm{b}[\AA]$ & $6.03522(5)$ & $6.046(8)$ & $6.026(8)$ & \multicolumn{7}{|c|}{$6.01(6)$} \\
\hline$c[\AA]$ & $11.213(1)$ & $11.248(8)$ & $11.240(5)$ & \multicolumn{7}{|c|}{$11.25(2)$} \\
\hline$B\left[^{\circ}\right]$ & $90.136(9)$ & $89.66(1)$ & $89.9(2)$ & \multicolumn{7}{|c|}{$89.3(2)$} \\
\hline Rwp & 10.57 & 9.27 & 14.09 & \multicolumn{7}{|c|}{7.59} \\
\hline GoF & 2.35 & 1.48 & 4.96 & \multicolumn{7}{|c|}{1.12} \\
\hline DW & 0.68 & 0.94 & 0.20 & \multicolumn{7}{|c|}{0.79} \\
\hline
\end{tabular}

For explanations see Tables 1 and 3

1.79 wt.\%) and silica (up to 1.23 wt. $\%$ ) were recognized. The mean chemical formula $(n=10)$ is: $\left(\mathrm{Cu}_{3.96} \mathrm{Al}_{0.04}\right)_{\Sigma 4.00}(\mathrm{SO} 4)_{1.00}$ $(\mathrm{OH})_{6} \cdot 1.90 \mathrm{H}_{2} \mathrm{O}$.

\section{MALACHITE $\mathrm{Cu}_{2}\left(\mathrm{CO}_{3}\right)(\mathrm{OH})_{2}$}

Malachite, a common secondary $\mathrm{Cu}$ mineral in the abandoned mine galleries, occurs in several forms. One of them comprise forms cryptocrystalline, earthy incrustations on the surface of chalcopyrite crystals undergoing weathering. Malachite also occurs as incrustations on the surface of rhyolites and schists that contain weathered chalcopyrite. The coatings are $\leq 2 \mathrm{~mm}$ thick and up to several tens of centimetres in diameter. Malachite of this type usually coexists with HCS, and signs of malachite-for-langite replacement are occasionally observed. The next morphological type is stalactitic. The length of malachite stalactites can reach a few centimetres. As a rule, the stalactites are soft. The PXRD patterns of the last morphological type show broadened reflections, indicating poor ordering of the structure. This is due to a relatively rapid rate of the stalactite formation. In places, malachite appears as spherical aggregates, $\leq 3 \mathrm{~mm}$ in diameter, built of thin needles. Locally these malachite aggregates are found within segregations of chalcoalumite or woodwardite. Ball-like malachite aggregates may also found within ferrihydrite accumulations that contain native copper, cuprite, HCS and small amounts of gypsum and amorphous Cu-Al sulphates.

\section{MOTTRAMITE PbCu( $\left(\mathrm{VO}_{4}\right)(\mathrm{OH})$}

Mottramite was identified by micro-area research and PXRD analysis (Table 7). Small segregations, $<20 \mu \mathrm{m}$ in size, were found at the first level of the abandoned mine where mottramite occurs at the border of goethite and chrysocolla (Fig. 2G). In places it also fills thin cracks cutting goethite. Mottramite is the only vanadate on the site and the only known Bi- and $\mathrm{Zn}$-bearing SCM. Contents of $\mathrm{Cu}$ vary from 1.01 to $1.16 \mathrm{apfu}$. Lead (from 0.87 to $0.98 \mathrm{apfu}$ ) is substituted by calcium (0.07-0.13 apfu) and bismuth (0.03-0.05 apfu). The composition corresponds to Ca-bearing arsenate mottramite. Such a replacement may be compared to the replacement reported for the bismuth-calcian variety of the species, called duhamelite (Krause et al., 2003). The chemical compositions of the mottramite at Radzimowice indicate significant substitutions on the anionic sites. The $\mathrm{VO}_{4}^{3-}$ ions (0.42-0.60 apfu) in the tetrahedral site are partially replaced by arsenate and phosphate ions (0.24-0.41 and 0.16-0.18 apfu, respectively). The approximate formula ( $n=$ 10) is: $\left(\mathrm{Pb}_{0.93} \mathrm{Ca}_{0.09} \mathrm{Bi}_{0.04}\right)_{\Sigma 1.06} \mathrm{Cu}_{1.06}\left[\left(\mathrm{~V}_{0.53} \mathrm{As}_{0.30} \mathrm{P}_{0.17}\right)_{\Sigma 1.00} \mathrm{O}_{4}\right](\mathrm{OH})_{1.54}$. A good negative correlation $\left(\mathrm{R}^{2}=0.95\right)$ between $\mathrm{Ca}^{2+}$ and $\mathrm{AsO}_{4}^{3-}$ could point to the analysed mottramite being an intermediate member of the conichalcite $\left[\mathrm{CaCu}\left(\mathrm{AsO}_{4}\right)(\mathrm{OH})\right]-$ mottramite series (e.g., Basso et al., 1989). However, the amount of $\mathrm{Ca}$ and $\mathrm{Bi}$ (replacing $\mathrm{Pb}$ ) is much smaller than the amount of As (replacing $\mathrm{V})$. The diadochy in the $\mathrm{Pb}-(\mathrm{Ca}+$ $\mathrm{Bi})$ system seems to be minor here. Thus, the mineral ana- 
Table 7

Chemical composition (wt.\%) and crystallographic data for mottramite from Radzimowice

\begin{tabular}{|c|c|c|c|c|c|c|c|c|c|c|}
\hline $\begin{array}{c}\text { Number } \\
\text { of } \\
\text { analyse }\end{array}$ & 1 & 2 & 3 & 4 & 5 & 6 & 7 & 8 & 9 & 10 \\
\hline $\mathrm{V}_{2} \mathrm{O}_{5}{ }^{1)}$ & 12.62 & 10.77 & 13.03 & 12.49 & 10.53 & 11.88 & 11.32 & 9.23 & 11.91 & 12.39 \\
\hline $\mathrm{As}_{2} \mathrm{O}_{5}$ & 7.37 & 8.78 & 6.75 & 7.22 & 9.06 & 8.08 & 8.54 & 11.37 & 8.18 & 7.50 \\
\hline $\mathrm{P}_{2} \mathrm{O}_{5}$ & 2.88 & 2.76 & 2.71 & 3.09 & 2.85 & 3.09 & 2.92 & 3.09 & 2.96 & 3.02 \\
\hline $\mathrm{Bi}_{2} \mathrm{O}_{3}$ & 1.90 & 2.04 & 1.53 & 2.13 & 2.29 & 2.12 & 2.01 & 2.78 & 2.06 & 1.74 \\
\hline $\mathrm{PbO}$ & 51.71 & 47.96 & 52.59 & 51.17 & 48.60 & 50.45 & 49.24 & 47.47 & 49.86 & 51.97 \\
\hline $\mathrm{CuO}$ & 19.96 & 21.65 & 19.99 & 20.23 & 20.82 & 19.58 & 20.93 & 21.19 & 19.75 & 19.80 \\
\hline $\mathrm{ZnO}$ & 0.09 & 0.06 & 0.00 & 0.06 & 0.00 & 0.14 & 0.10 & 0.00 & 0.00 & 0.07 \\
\hline $\mathrm{CaO}$ & 1.02 & 1.40 & 0.89 & 0.99 & 1.33 & 1.32 & 1.15 & 1.80 & 1.27 & 1.10 \\
\hline$\Sigma$ & 97.55 & 95.42 & 97.49 & 97.38 & 95.48 & 96.66 & 96.21 & 96.93 & 95.99 & 97.59 \\
\hline $\mathrm{H}_{2} \mathrm{O}^{2)}$ & 2.45 & 4.58 & 2.51 & 2.62 & 4.52 & 3.34 & 3.79 & 3.07 & 4.01 & 2.41 \\
\hline \multicolumn{11}{|c|}{ apfu (base: $V+A s+P=1$ ) } \\
\hline $\mathrm{V}$ & 0.57 & 0.51 & 0.60 & 0.56 & 0.49 & 0.53 & 0.52 & 0.42 & 0.54 & 0.56 \\
\hline As & 0.26 & 0.33 & 0.24 & 0.26 & 0.34 & 0.29 & 0.31 & 0.41 & 0.29 & 0.27 \\
\hline $\mathrm{P}$ & 0.17 & 0.17 & 0.16 & 0.18 & 0.17 & 0.18 & 0.17 & 0.18 & 0.17 & 0.17 \\
\hline $\mathrm{Bi}$ & 0.03 & 0.04 & 0.03 & 0.04 & 0.04 & 0.04 & 0.04 & 0.05 & 0.04 & 0.03 \\
\hline $\mathrm{Pb}$ & 0.95 & 0.92 & 0.98 & 0.94 & 0.93 & 0.92 & 0.92 & 0.87 & 0.92 & 0.95 \\
\hline $\mathrm{Cu}$ & 1.03 & 1.16 & 1.05 & 1.04 & 1.11 & 1.01 & 1.10 & 1.09 & 1.02 & 1.02 \\
\hline $\mathrm{Zn}$ & & & & & & 0.01 & 0.01 & & & \\
\hline $\mathrm{Ca}$ & 0.07 & 0.11 & 0.07 & 0.07 & 0.10 & 0.10 & 0.09 & 0.13 & 0.09 & 0.08 \\
\hline $\mathrm{OH}$ & 1.12 & 2.18 & 1.16 & 1.19 & 2.14 & 1.52 & 1.75 & 1.40 & 1.83 & 1.10 \\
\hline \multicolumn{11}{|c|}{ unit cell parameters (with refinement statistics) } \\
\hline $\mathrm{a}[\AA]$ & \multicolumn{10}{|c|}{$8.98(3)$} \\
\hline $\mathrm{b}[\AA]$ & \multicolumn{10}{|c|}{$10.77(3)$} \\
\hline$c[\AA]$ & \multicolumn{10}{|c|}{$6.75(2)$} \\
\hline Rwp & \multicolumn{10}{|c|}{1.39} \\
\hline GoF & \multicolumn{10}{|c|}{1.10} \\
\hline DW & \multicolumn{10}{|c|}{1.78} \\
\hline
\end{tabular}

1) wt. \% values for $\mathrm{SO}_{3}, \mathrm{SiO}_{2}, \mathrm{Al}_{2} \mathrm{O}_{3}$ and $\mathrm{FeO}$ omitted, as always equaling $0.00 ;{ }^{2)}$ calculated as $100-\Sigma$; for other explanations see Table 1

lysed should rather be placed in the mottramite - duftite series. Brugger et al. (2001) suggest the existence of mottramite - tangeite $\left[\mathrm{CaCu}\left(\mathrm{VO}_{4}\right)(\mathrm{OH})\right]$ solid solution. However, a negative correlation between $\mathrm{Ca}^{2+}$ and $\mathrm{VO}_{4}^{3-}$ excludes the Radzimowice mottramite from belonging to that series. Confirmed cases of the presence of solid solutions between mottramite and minerals of the adelite group are rarely found in the literature (Lazebnik and Zajakina, 1988). The chemical composition of mottramite from the abandoned mine galleries at Radzimowice confirms the existence of such isomorphous series.

\section{NATIVE COPPER Cu}

Native copper was reported in the 19th century by Traube (1888) as dendritic aggregates observed in thin fissures of green schists. Dendrites of native copper were built by small crystals formed as dodecahedrons. The presence of native copper in association with hematite and pitticite in the near-surface part of the Radzimowice deposit was noticed by Berg
(1913). The presence of native copper precipitating on steel rails was also noticed by Stauffacher (1916).

During study of the secondary copper minerals occurring in abandoned mine pits, two types of native copper were distinguished. The first type is native copper forming single dendrites, $\leq 3 \mathrm{~cm}$ long, sitting in the segregations of ferrihydrite (Fig. 4D). At several localities within the mine pits native $\mathrm{Cu}$ is associated with cuprite, brochantite, langite, posnjakite, malachite and small amounts of chalcoalumite and amorphous sulphates of $\mathrm{Cu}$ and Al. The dendrites are locally ingrown in tabular, transparent gypsum crystals, coexisting with pitticite. In places the dendrites form spongy accumulations, up to a dozen or so centimetres in diameter, occurring within the stalagmites of iron oxyhydroxides. The second type of copper is observed in the vicinity of steel objects left in old mining galleries. The moss-like aggregates of such copper are up to few centimetres in size. Both types of native copper form crystals which usually are combinations of cubes and octahedra. The octahedron face may be skeletal (Fig. 2H). In many cases, two generations of copper are observed, the older of which has cubic habit, while the younger epitaxially grows on the edges, representing a 
combination of octahedron, rhombic dodecahedron and gyroid. Copper twins on the octahedral faces are common.

Electron microprobe analysis of the dendritic copper from ferrihydrite stalagmites showed that the chemical composition is very pure. Minor concentrations of iron (0.10-0.62 wt.\%) are likely due to the presence of tiny inclusions of Fe oxyhydroxides in the material analysed.

\section{POSNJAKITE $\mathrm{Cu}_{4}\left(\mathrm{SO}_{4}\right)(\mathrm{OH})_{6} \cdot 2 \mathrm{H}_{2} \mathrm{O}$}

The hydrous copper sulphate mineral posnjakite is found in two settings. Posnjakite forms light blue dendritic crystals and thin tabular crystals, $\leq 1 \mathrm{~mm}$ long (Fig. 4E) on the surface of rhyolitic rocks which contain weathered chalcopyrite. The posnjakite is associated with brochantite, langite, malachite and small amounts of devilline. Locally these minerals grow with other base copper sulphates on the wooden shaft support pillars. The second type of posnjakite occurrence is its association with Fe-oxyhydroxide (mainly ferrihydrite) dropstones. Such posnjakite fills small cavities in central parts of the dropstones or grows on the surface of copper-cuprite aggregates with langite (Fig. 4F). In this case, posnjakite coexists with small amounts of malachite, gypsum, chalcoalumite, and amorphous Cu-Al sulphates.

In both types, a replacement of langite crystals by posnjakite microcrystalline aggregates (see above) was observed.
Such a process has also been recorded by other authors e.g., Komkov and Fefedov (1967).

The X-ray powders patterns of posnjakite from Radzimowice correspond well to the data published for this mineral. The parameters $b$ and $c$ fit well into the general trend extending from 6.33 to $6.35 \AA$ and ca. 7.84 to ca.7.90 $\AA$, respectively (Table 8). Other lattice parameters are practically invariable if one analyses the published data.

The chemical composition of posnjakite was determined by WDS analysis (Table 8 ). The quantitative chemical study shows small impurities of aluminium ( $\leq 0.08 \mathrm{apfu}$ ) and silica ( $\leq 0.11 \mathrm{apfu})$. The empirical formula of posnjakite from Radzimowice $(n=10)$ is as follow: $\left(\mathrm{Cu}_{3.97} \mathrm{Al}_{0.03}\right)_{\Sigma 4.00}\left[\left(\mathrm{SO}_{4}\right)_{0.95}\left(\mathrm{SiO}_{4}\right)_{0.05}\right]_{\Sigma 1.00}(\mathrm{OH})_{6} \cdot 1.95 \mathrm{H}_{2} \mathrm{O}$. Posnjakite follows the same tendency of concentrating some $\mathrm{Al}$ and $\mathrm{Si}$ as does langite.

\section{WOODWARDITE $\mathrm{Cu}_{4} \mathrm{Al}_{2}\left(\mathrm{SO}_{4}\right)(\mathrm{OH})_{16} \cdot 2-4 \mathrm{H}_{2} \mathrm{O}$}

Woodwardite, a mineral giving its name to a group of similar compounds, forms cryptocrystalline covers, deep to light blue, precipitating on the walls of mine galleries down which mine drainage water is flowing (Fig. 3B). They comprise spheroidal or oval aggregates (Fig. 5A). Even high-magnification imaging could not reveal the crystal habit within them. Locally also loose, non-consolidated accumulations of this mineral are found. Woodwardite is usually associated with small amounts of mala-

Chemical composition (wt.\%) and crystallographic data of posnjakite from Radzimowice

\begin{tabular}{|c|c|c|c|c|c|c|c|c|c|c|}
\hline $\begin{array}{c}\text { Number } \\
\text { of } \\
\text { analyse }\end{array}$ & 1 & 2 & 3 & 4 & 5 & 6 & 7 & 8 & 9 & 10 \\
\hline $\mathrm{P}_{2} \mathrm{O}_{5}$ & 0.09 & 0.00 & 0.00 & 0.00 & 0.00 & 0.00 & 0.00 & 0.00 & 0.00 & 0.00 \\
\hline $\mathrm{SO}_{3}$ & 16.57 & 15.86 & 17.72 & 15.86 & 15.97 & 16.98 & 15.74 & 16.47 & 16.90 & 15.60 \\
\hline $\mathrm{SiO}_{2}$ & 1.06 & 0.00 & 1.35 & 0.00 & 0.00 & 1.28 & 0.21 & 1.38 & 0.00 & 0.45 \\
\hline $\mathrm{Fe}_{2} \mathrm{O}_{3}$ & 0.00 & 0.00 & 0.34 & 0.00 & 0.00 & 0.02 & 0.00 & 0.00 & 0.00 & 0.00 \\
\hline $\mathrm{Al}_{2} \mathrm{O}_{3}$ & 0.56 & 0.00 & 0.72 & 0.00 & 0.20 & 0.77 & 0.26 & 0.09 & 0.00 & 0.60 \\
\hline $\mathrm{CuO}$ & 63.38 & 65.61 & 61.45 & 65.57 & 66.68 & 62.58 & 65.56 & 65.01 & 64.94 & 63.95 \\
\hline$\Sigma$ & 81.66 & 81.47 & 81.58 & 81.43 & 82.85 & 81.63 & 81.77 & 82.95 & 81.84 & 80.60 \\
\hline $\mathrm{H}_{2} \mathrm{O}^{1)}$ & 18.34 & 18.53 & 18.42 & 18.57 & 17.15 & 18.37 & 18.23 & 17.05 & 18.16 & 19.40 \\
\hline \multicolumn{11}{|c|}{ apfu (base: $\mathrm{Cu}+\mathrm{Al}=4$ ) } \\
\hline$P$ & 0.01 & & & & & & & & & \\
\hline$S$ & 1.02 & 0.96 & 1.12 & 0.96 & 0.95 & 1.06 & 0.95 & 1.00 & 1.03 & 0.96 \\
\hline $\mathrm{Si}$ & 0.09 & & 0.11 & & & 0.11 & 0.02 & 0.11 & & 0.04 \\
\hline $\mathrm{Al}$ & 0.05 & & 0.07 & & 0.02 & 0.08 & 0.02 & 0.01 & & 0.06 \\
\hline $\mathrm{Cu}$ & 3.95 & 4.00 & 3.91 & 4.00 & 3.98 & 3.92 & 3.98 & 3.99 & 4.00 & 3.94 \\
\hline $\mathrm{Fe}^{2+}$ & & & 0.02 & & & & & & & \\
\hline \multicolumn{11}{|c|}{ unit cell parameters (with refinement statistics) } \\
\hline Sample & pos 1 & pos 2 & \multicolumn{8}{|c|}{ pos 3} \\
\hline$a[\AA]]$ & $10.557(1)$ & $10.55(2)$ & \multicolumn{8}{|c|}{$10.497(4)$} \\
\hline $\mathrm{b}[\AA]]$ & $6.3326(8)$ & $6.35(1)$ & \multicolumn{8}{|c|}{$6.33(2)$} \\
\hline$c[\AA]$ & $7.847(1)$ & $7.81(1)$ & \multicolumn{8}{|c|}{$7.87(3)$} \\
\hline$B\left[^{\circ}\right]$ & $117.977(8)$ & $117.5(2)$ & \multicolumn{8}{|c|}{ 118.1(4) } \\
\hline Rwp & 9.27 & 14.09 & \multicolumn{8}{|c|}{10.57} \\
\hline GoF & 1.48 & 4.96 & \multicolumn{8}{|c|}{2.35} \\
\hline DW & 0.94 & 0.20 & \multicolumn{8}{|c|}{0.68} \\
\hline
\end{tabular}



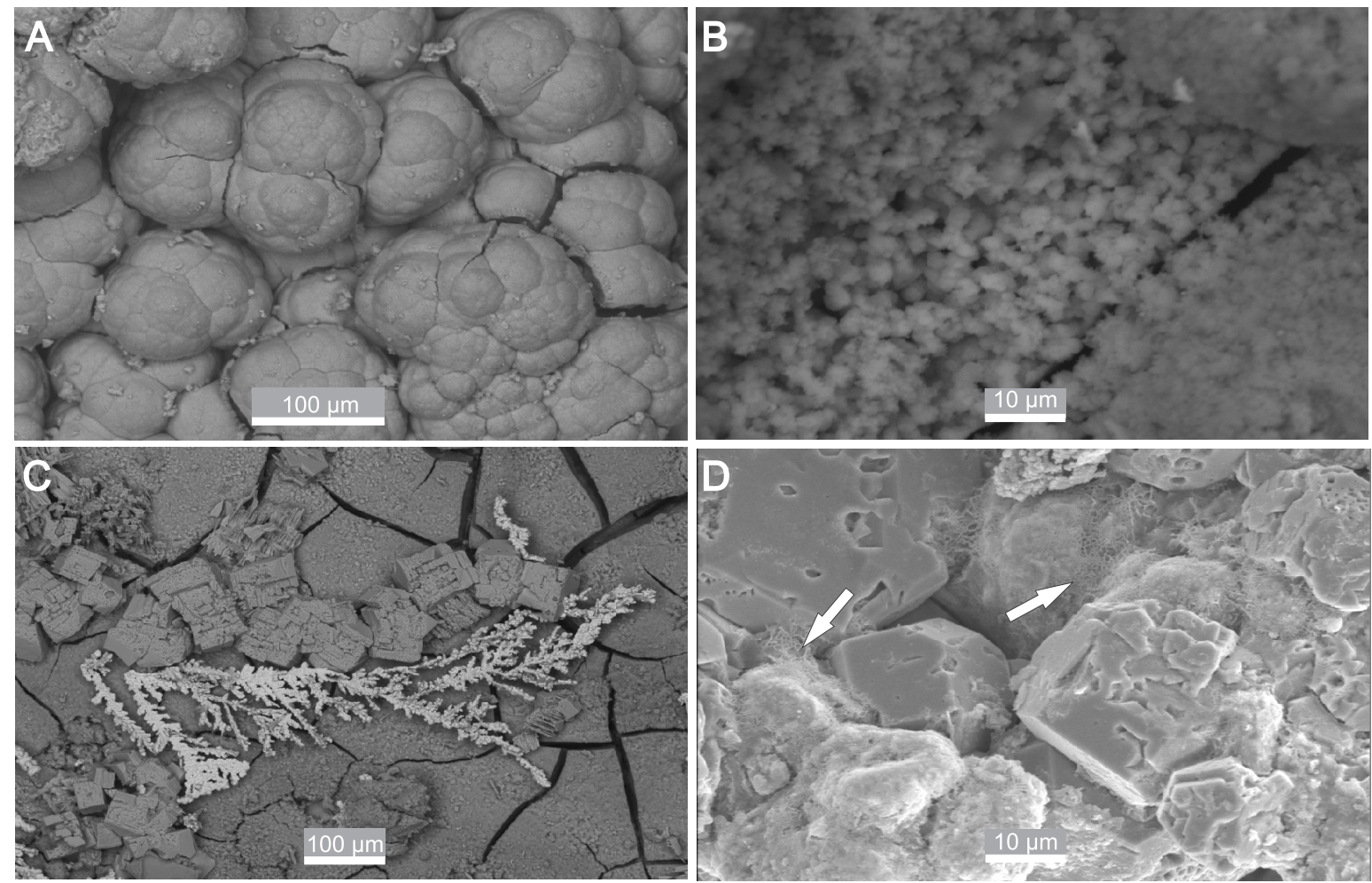

Fig. 5. SEM images of secondary copper minerals from Radzimowice

A - spherical aggregates of woodwardite, B - aggregates of amorphous Cu-Al sulphates, C - cracked pitticite coexisting with langite and native copper, $\mathbf{D}$ - cuprite crystals with traces of dissolution, partly covered

by irregular aggregates of HCS (indicate by arrows)

chite, langite, chalcoalumite, amorphous silica and $\mathrm{Cu}-\mathrm{Al}$ sulphates. The Rietveld refinement gives unit cell parameters in agreement with published values. Woodwardite is practically indistinguishable from chalcoalumite by PXRD. Nevertheless, the best refinement results are obtained when including this phase. The calculated crystallite size (Lorentzian) is around 222(98) nanometres, suggesting that woodwardite is more crystalline than chalcoalumite. Nickel (1976) reports the following $d$ values for reflections of the Cornwall (real) woodwardite: 9.1, 4.43 (weak, broad and diffuse), 2.58 and $1.50 \AA$. Tiny, shoulder-like reflection $\sim 9 \AA$ are observed on all the diffractograms and the corresponding $\{003\}$ basal reflection is often asymmetrical. Reflections at $\sim 4.50-4.44 \AA$ were also noticed and are also very weak and diffuse. A broad reflection at $2.60 \AA$ is evident in two of three samples under study. One or two very diffuse reflections with d values of the 1.50-1.54 A range can be seen in diffractograms of at least one sample.

The IR spectrum of the woodwardite is characterized by several absorption bands. Woodwardite contains two types of water - water molecules and hydroxyl ions. The main $\mathrm{OH}$ stretching vibration is observed at $3425 \mathrm{~cm}^{-1}$. A strong peak observed at $1635 \mathrm{~cm}^{-1}$ is associated with $\delta_{\mathrm{w}}$ water bending modes of $\mathrm{H}_{2} \mathrm{O}$ molecules. The presence of $\mathrm{SO}_{4}^{2-}$ ions is confirmed by several absorption bands characteristic of this anion (Schmidt and Lutz, 1993; Frost et al., 2010). The intensive band at $1116 \mathrm{~cm}^{-1}$ is assigned to the asymmetrical stretching mode of sulphate ions $\left(v_{3}\right)$, and the one at $976 \mathrm{~cm}^{-1}$ to the symmetrical stretching mode of these ions $\left(v_{1}\right)$. The band with a maximum at $611 \mathrm{~cm}^{-1}$ is assigned to out-of-plane bending modes $\left(\mathrm{v}_{4}\right)$. In the IR spectra several bands indicative of carbonate groups were also noticed, namely at 1521, 1430, 1399, $819 \mathrm{~cm}^{-1}$ and $667 \mathrm{~cm}^{-1}$. The occurrence of these bands could be explained by the presence of small inclusions of malachite, known to be closely associated with woodwardite. On the other hand, small amounts of carbonate ions have been detected in hydrotalcitelike sulphate minerals from different sites (e.g., Nickel, 1976; Bish and Livingstone, 1981; Raade et al., 1985). This is suggestive of partial carbonate-for-sulphate replacement in the structure of the woodwardite from Radzimowice.

\section{WROEWOLFEITE $\mathrm{CU}_{4}\left(\mathrm{SO}_{4}\right)(\mathrm{OH})_{6} \cdot 2 \mathrm{H}_{2} \mathrm{O}$}

Wroewolfeite forms thin-bladed, light green crystals $\leq 0.2 \mathrm{~mm}$ in size. The crystals grow on the surface of rhyolites, associated with thin needles of malachite. No wroewolfeite was found in assemblages with other HCS.

This mineral was identified by X-ray powder diffraction; the refined unit-cell parameters are in good agreement with the published data (Table 9). A quantitative chemical analysis of wroewolfeite is shown in Table 9. The mineral analysed is relatively pure; the minor admixtures include iron (from 0.23 to 3.10 wt. $\% \mathrm{Fe}_{2} \mathrm{O}_{3}$ ), aluminium (to 0.28 wt. $\% \mathrm{Al}_{2} \mathrm{O}_{3}$ ), phosphorus (up to 0.12 wt. $\left.\% \mathrm{P}_{2} \mathrm{O}_{5}\right)$ and silica $\left(0.82\right.$ wt. $\left.\% \mathrm{SiO}_{2}\right)$. The empiri- 
Table 9

Chemical composition (wt.\%) and crystallographic data for wroewolfeite from Radzimowice

\begin{tabular}{|c|c|c|c|c|c|c|c|c|}
\hline $\begin{array}{c}\text { Number } \\
\text { of } \\
\text { analyse }\end{array}$ & 1 & 2 & 3 & 4 & 5 & 6 & 7 & 8 \\
\hline $\mathrm{P}_{2} \mathrm{O}_{5}$ & 0.09 & 0.00 & 0.10 & 0.12 & 0.00 & 0.00 & 0.00 & 0.00 \\
\hline $\mathrm{SO}_{3}$ & 15.16 & 13.23 & 13.51 & 14.91 & 14.52 & 14.34 & 14.24 & 14.93 \\
\hline $\mathrm{SiO}_{2}$ & 0.17 & 0.20 & 0.82 & 0.00 & 0.08 & 0.15 & 0.00 & 0.00 \\
\hline $\mathrm{Fe}_{2} \mathrm{O}_{3}$ & 0.37 & 0.96 & 3.10 & 0.23 & 0.57 & 0.27 & 0.29 & 0.32 \\
\hline $\mathrm{Al}_{2} \mathrm{O}_{3}$ & 0.09 & 0.06 & 0.28 & 0.00 & 0.05 & 0.08 & 0.00 & 0.00 \\
\hline $\mathrm{CuO}$ & 66.99 & 68.15 & 64.61 & 67.24 & 66.48 & 67.47 & 67.10 & 66.71 \\
\hline$\Sigma$ & 82.87 & 82.60 & 82.42 & 82.50 & 81.70 & 82.31 & 81.63 & 81.96 \\
\hline $\mathrm{H}_{2} \mathrm{O}^{1)}$ & 17.13 & 17.40 & 17.58 & 17.50 & 18.30 & 17.69 & 18.37 & 18.04 \\
\hline \multicolumn{9}{|c|}{ apfu (base: $\mathrm{Cu}+\mathrm{Fe}+\mathrm{Al}=4$ ) } \\
\hline $\mathrm{P}$ & 0.01 & & 0.01 & 0.01 & & & & \\
\hline$S$ & 0.89 & 0.76 & 0.79 & 0.88 & 0.86 & 0.84 & 0.84 & 0.89 \\
\hline Si & 0.01 & 0.02 & 0.06 & & 0.01 & 0.01 & & \\
\hline $\mathrm{Fe}^{2+}$ & 0.02 & 0.06 & 0.18 & 0.01 & 0.03 & 0.02 & 0.02 & 0.02 \\
\hline $\mathrm{Al}$ & 0.01 & 0.01 & 0.03 & & & 0.01 & & \\
\hline $\mathrm{Cu}$ & 3.97 & 3.94 & 3.79 & 3.99 & 3.96 & 3.98 & 3.98 & 3.98 \\
\hline \multicolumn{9}{|c|}{ unit cell parameters (with refinement statistics) } \\
\hline $\mathrm{a}[\AA]$ & \multicolumn{8}{|c|}{$5.989(8)$} \\
\hline $\mathrm{b}[\AA]$ & \multicolumn{8}{|c|}{$5.709(8)$} \\
\hline$c[\AA]$ & \multicolumn{8}{|c|}{$14.328(7)$} \\
\hline$ß\left[^{\circ}\right]$ & \multicolumn{8}{|c|}{$93.1(2)$} \\
\hline Rwp & \multicolumn{8}{|c|}{4.08} \\
\hline GoF & \multicolumn{8}{|c|}{1.36} \\
\hline DW & \multicolumn{8}{|c|}{1.17} \\
\hline
\end{tabular}

For explanations see Tables 1 and 3

\section{SECONDARY CU MINERAL PARAGENESES AND THEIR FORMATION CONDITIONS}

Several characteristic mineral parageneses are distinguished (Table 10) based on our study of SCM recently formed in abandoned mine galleries in Radzimowice. These distinct parageneses differ by mineral composition and by frequency of occurrence. The variability of parageneses of secondary $\mathrm{Cu}$ minerals from Radzimowice reflects different formation conditions within the oxidation zone, the composition of the primary ore minerals, the mineral composition of host rocks, and activities of particular ions in waters circulating in the oxidation zone. The main $\mathrm{Cu}$ ore mineral is chalcopyrite. This sulphide oxidizes relatively slowly under the influence of atmospheric oxygen and water [reaction 1]:

$$
\begin{gathered}
\mathrm{CuFeS}_{2}+4.25 \mathrm{O}_{2}+1.5 \mathrm{H}_{2} \mathrm{O} \rightarrow \mathrm{Cu}^{2+}+2 \mathrm{SO}_{4}^{2-}+ \\
+4 \mathrm{H}^{+}+\mathrm{FeO}(\mathrm{OH})
\end{gathered}
$$

This process leads to slight $\mathrm{pH}$ decrease. Reaction [1] is catalysed by the presence of $\mathrm{Fe}^{3+}$ ions (Klauber et al., 2001; Maley et al., 2009). The source of the ferric iron is the oxidation of pyrite associated with chalcopyrite, according to the reactions [2 and 3]:

$$
\mathrm{FeS}_{2}+3.5 \mathrm{O}_{2}+\mathrm{H}_{2} \mathrm{O} \rightarrow \mathrm{Fe}^{2+}+2 \mathrm{SO}_{4}^{2-}+2 \mathrm{H}^{+}
$$

$$
\mathrm{Fe}^{2+}+0.25 \mathrm{O}^{2}+\mathrm{H}^{+} \rightarrow \mathrm{Fe}^{3+}+0.5 \mathrm{H}_{2} \mathrm{O}
$$

Pyrite decomposition leads to a drastic drop of cal formula of the wroewolfeite $(n=8)$ may be written as $\left(\mathrm{Cu}_{3.95} \mathrm{Fe}_{0.04} \mathrm{Al}_{0.01}\right)_{\Sigma 4.00}\left[\left(\mathrm{SO}_{4}\right)_{0.84}\left(\mathrm{SiO}_{4}\right)_{0.01}\right]_{\Sigma 0.85}(\mathrm{OH})_{6} \cdot 1.63 \mathrm{H}_{2} \mathrm{O}$.

\section{OTHER MINERALS COEXISTING WITH SCM}

Ferrihydrite is the most common mineral associated with SCM at the study site. It is usually present as stalagmites or stalactites, less than tens of centimetres in length. The mineral is very often present as loose accumulations, up to 1 or even $2 \mathrm{~m}$ thick, lying at the bottom of old mine pits. Ferrihydrite is accompanied by goethite. Schwertmannite appears in zones of inflow of very pH-low waters. SCM that occur within ferrihydrite accumulations typically are associated with gypsum.

Amorphous phases that produce very weak or no XRD response also occur at the study site as thin crusts of light blue or blue-green colour. They usually coexist with chalcoalumite or woodwardite and may also form loose fillings occluding open spaces of ferrihydrite stalactites. High magnification SEM images show that the amorphous crusts form botryoidal aggregates (Fig. 5B). The chemical composition of the aggregates is variable, and various $\mathrm{Cu} / \mathrm{Al}$ ratios were obtained. In some cases, small accumulations of pitticite, an amorphous hydrous ferric arsenate-sulphate, were found near native copper and Cu minerals replacing copper (Fig. 5C). This phase is strongly cracked, russet-black, of resinous luster and conchoidal fracture. $\mathrm{pH}$ within the environment [reaction 4] and produces chemically aggressive acidic mine waters (AMD).

$$
\begin{gathered}
\mathrm{FeS}_{2}+14 \mathrm{Fe}^{3+}+8 \mathrm{H}_{2} \mathrm{O} \rightarrow 15 \mathrm{Fe}^{2+}+ \\
+2 \mathrm{SO}_{4}^{2-}+16 \mathrm{H}^{+}
\end{gathered}
$$

Acid mine drainage and weathering of pyritic schists are observed at Radzimowice (Parafiniuk and Siuda, 2006). The action of acid mine waters on barren rocks is well-known (Parafiniuk, 1996; Nordstrom and Alpers, 1999; Marini et al., 2003; Bowell and Parshley, 2005; Hammarstrom et al., 2005). Under reduced $\mathrm{pH}$ conditions, some rock-forming minerals including chlorites in schists and plagioclases in rhyolites undergo decomposition. This causes Al liberation and its incorporation into solutions. Aluminium remains in solution as long as $\mathrm{pH}$ is sufficiently low. The rise in $\mathrm{pH}$ leads to binding of $\mathrm{Al}$ in secondary Cu-Al mineral species. Such decomposition of rockforming aluminosilicates plays an important role in the formation of secondary Cu minerals at Radzimowice.

The first paragenesis (no. I) includes HCS - langite, posnjakite, brochantite, devilline and malachite. Minerals of this assemblage crystallise directly from mine waters flowing down the mine sidewalls. Neither gypsum nor Fe oxyhydroxides were identified in this paragenesis. The crystallisation of a particular $\mathrm{HCS}$ is modelled by both the concentration of $\mathrm{SO}_{4}^{2-}$ ions in solution and its $\mathrm{pH}$. Generally formation of posnjakite is likely pre- 
Mineral parageneses of secondary copper minerals from an abandoned mine at Radzimowice

\begin{tabular}{|l|r|}
\hline Paragenesis & Mineral composition ${ }^{1}$ \\
\hline I & langite, posnjakite, brochantite, devilline, malachite \\
\hline II & $\begin{array}{r}\text { langite, posnjakite, brochantite, malachite, chalcoaluminte, gypsum, cuprite, native copper, ferrihydrite, } \\
\text { amorphous Cu-Al sulphates, goethite, pitticite }\end{array}$ \\
\hline III & woodwardite, chalcoalumite, langite, malachite, amorphous Cu-Al sulphates \\
\hline IV & chrysocolla, goethite, mottramite \\
\hline
\end{tabular}

\footnotetext{
${ }^{1}$ minor or accessory minerals in italic
}

ceded by the precipitation of amorphous HCS that tend to quickly transform into posnjakite (Krätschmer et al., 2002). Besides posnjakite, langite also forms early in paragenesis I. Both sulphates are stabilized by relatively high a $\mathrm{SO}_{4}^{2-}$ (Dabinett et al., 2008) and $\mathrm{pH}$ values, the latter varying from 6.0 to 7.5 (Alwan and Williams, 1979).

An inflow of greater amounts of groundwater in humid seasons causes a decrease in $\mathrm{SO}_{4}^{2-}$ and $\mathrm{Cu}^{2+}$ ion concentrations and a change of $\mathrm{pH}$, which causes posnjakite and langite dissolution. This is shown by dissolution traces observed at the surface of langite crystals and also by the lack of brochantite pseudomorphoses after langite. Solutions with lowered $\mathrm{Cu}^{2+}$ and $\mathrm{SO}_{4}^{2-}$ concentrations are parental for brochantite. This mineral is the most stable HCS, forming at a $\mathrm{pH}$ range of 4-7.5 (Marani et al., 1995; Fitzgerald et al., 2006; Kaş and Birer, 2012). As Maley et al. (2009) showed, the drop of $\mathrm{pH}$ below the value of 3 rapidly causes dissolution of brochantite. Furthermore, no antlerite, which crystallises at $\mathrm{pH}<4$ (Pollard et al., 1992; Fuente et al., 2008), or tenorite, stable by pH >8 (Fitzgerald et al., 1998; Frost, 2003) were found. The rarest HCS found within paragenesis $I$ is devilline. Its presence reflects locally high $\mathrm{Ca}^{2+}$ ion activity in the mine waters. The changing chemistry of these solutions is also confirmed by the presence of malachite, which forms over a wide range of $\mathrm{CO}_{3}^{2-}$ ion concentrations (Vink, 1986). Malachite may crystallise directly from the solution [reaction 5]:

$$
2 \mathrm{Cu}^{2+}+\mathrm{CO}_{3}^{2-}+2 \mathrm{OH}^{-} \rightarrow \mathrm{Cu}_{2}\left(\mathrm{CO}_{3}\right)(\mathrm{OH})_{2}
$$

If the activity of $\mathrm{SO}_{4}^{2-}$ ions falls and the concentration of $\mathrm{CO}_{3}^{2-}$ ions rise within the solution, malachite may replace previously formed HCS (Woods and Garrels, 1986; Clissold et al., 2005). This process is described by reaction [6]:

$$
\begin{gathered}
\mathrm{Cu}_{4} \mathrm{SO}_{4}(\mathrm{OH})_{6} \cdot 2 \mathrm{H}_{2} \mathrm{O}+2 \mathrm{CO}_{3}^{2-}+ \\
+4 \mathrm{H}^{+} \rightarrow 2 \mathrm{Cu}_{2}\left(\mathrm{CO}_{3}\right)(\mathrm{OH})_{2}+\mathrm{SO}_{4}^{2-}+4 \mathrm{H}_{2} \mathrm{O}+2 \mathrm{H}^{+}
\end{gathered}
$$

This reaction explains the formation of malachite pseudomorphs after langite in paragenesis I. On the basis of modelling done by Alwan and Williams (1979) for a langite/brochantite-malachite assemblage from Cornwall, one may conclude that this process takes place at $\mathrm{pH} 6.0-7.5$ and depends on $\mathrm{aCO}_{3}^{2-}$ in solution. A rise of $\mathrm{a} \mathrm{CO}_{3}^{2-}$, due to seasonal inflow of rain water, causes disequilibrium between $\mathrm{HCS}$ and malachite.

The absence of wroewolfeite in paragenesis I is likely due to the prevailing $\mathrm{pH}$ conditions. Wroewolfeite is known, e.g., from efflorescences precipitating from Cu-rich AMD at the Kirki de- posit, Greece (Triantafyllidis and Skarpelis, 2006). In this deposit wroewolfeite is formed at low pH, i.e. $\sim 3$. This is at variance with the data of Dabinett et al. (2008), that find wroewolfeite, the less stable HCS, crystallising by $\mathrm{pH} \sim 6$. The rarity of the occurrence of wroewolfeite in the Radzimowice mine may be due to elevated concentrations of $\mathrm{Mg}$ in the mine waters (Parafiniuk and Siuda, 2006). Dabinett et al. (2008) noticed that the presence of $\mathrm{Mg}^{2+}$ in solution inhibits nucleation of wroewolfeite while promoting the formation of posnjakite.

HCS are also the dominant minerals that characterize paragenesis II. However, native copper, cuprite and gypsum and small amounts of chalcoalumite and amorphous Cu-Al sulphates also are present. The minerals of this paragenesis are found exclusively within accumulations of Fe oxyhydroxides with ferrihydrite as the main phase. Native copper forms by reduction of $\mathrm{Cu}^{2+}$ ions by $\mathrm{Fe}^{2+}$ ions, following reaction [7], with $\mathrm{Fe}$ removed from the solution by the simultaneous precipitation of ferrihydrite:

$$
\mathrm{Cu}^{2+}+2 \mathrm{Fe}^{2+} \rightarrow \mathrm{Cu}^{0}+2 \mathrm{Fe}^{3+}
$$

Cuprite crystallises at the surface of native copper, according to the reaction [8]:

$$
2 \mathrm{Cu}+0.5 \mathrm{O}_{2} \rightarrow \mathrm{Cu}_{2} \mathrm{O}
$$

Cuprite acts as a precursor for further secondary Cu minerals, such as carbonates and hydrous sulphates (Fitzgerald et al., 1998; Mendoza et al., 2004; Fuente et al., 2008). The surfaces of cuprite crystals reveal traces of dissolution and may be covered by HCS (Fig. 5D). This indicates cuprite dissolution in the presence of $\mathrm{SO}_{4}^{2-}$ ions and replacement by $\mathrm{HCS}$, according to reaction [9]:

$$
\begin{gathered}
2 \mathrm{Cu}_{2} \mathrm{O}+\mathrm{SO}_{4}^{2-}+6 \mathrm{H}_{2} \mathrm{O} \rightarrow \mathrm{Cu}_{4} \mathrm{SO}_{4}(\mathrm{OH})_{6} . \\
\cdot 2 \mathrm{H}_{2} \mathrm{O}+2 \mathrm{H}^{+}
\end{gathered}
$$

HCS formed this way may substitute the cuprite-copper aggregates. Langite and posnjakite of this paragenesis can transform into brochantite, as in the case of paragenesis I. The other secondary $\mathrm{Cu}$ minerals are insignificant in paragenesis II. The occurrence of small amounts of malachite may attest to a seasonal inflow of waters enriched in $\mathrm{CO}_{3}^{2-}$ ions. Coexistence of secondary Cu minerals with ferrihydrite allows for the recognition of crystallisation conditions of these phases. Ferrihydrite precipitates from solutions of $\mathrm{pH}<5.5$. By pH 6.5, ferrihydrite begins to dominate (e.g., Bigham et al., 1996; Yu et 
al., 1999; Murad and Rojík, 2003). At the same time, the presence of brochantite is indicative of $\mathrm{pH}$ of the 4-7.5 range (Bridges and Green, 2007). The presence of gypsum indicates that the value of $\mathrm{SO}_{4}^{2-}$ should be close to $10^{-2.5} \mathrm{~mol} / \mathrm{l}$, that is the saturation concentration of gypsum. Taking this value under consideration, the stability fields of brochantite and ferrihydrite overlap in the $\mathrm{pH}$ range of $\sim 5-6$. Importantly, tenorite, which is stable at higher $\mathrm{pH}$ values, was not identified within paragenesis II.

Paragenesis III at Radzimowice is dominated by woodwardite, with minor langite, chalcoalumite and malachite. Woodwardite accumulates in zones 2-3 metres wide, where mixing of AMD waters with chemically unchanged groundwaters occurs. At the contact of these waters a clear separation of Fe-rich precipitates of AMD waters from blue deposit of $\mathrm{Cu}-\mathrm{Al}$ sulphates was observed (Fig. $3 \mathrm{C}$ ). Such a contact zone is a natural geochemical barrier. The blue deposit of woodwardite binds $\mathrm{Al}$ that is removed from solution under the conditions of elevated $\mathrm{pH}$. The presence of langite points to the $\mathrm{pH}$ of the parent solutions being around 6-7.5, which is consistent with the values observed by Dinelli et al. (1998) and Marini et al. (2003) for blue deposits of Cu-Al sulphates precipitating from mine waters of the Vigonzano and Libiola areas, Italy. Hydrogeochemical modelling and field observations carried out by Tumiati et al. (2008) show that woodwardite crystallise by $\mathrm{pH}$ of 7.39-7.55 from $\mathrm{CO}_{2}$-undersaturated solutions, i.e., with $\mathrm{CO}_{2}$ concentration $<10^{-4} \mathrm{~mol} / \mathrm{l}$. An increase of $\mathrm{CO}_{2}$ concentration leads to the formation of malachite and other carbonate-bearing minerals (Stara et al., 1999).

The last paragenesis recently forming in abandoned mine galleries comprises chrysocolla, goethite and mottramite. These minerals occur at the surface of a joint cutting rhyolite. Along this surface, migration of solutions rich in metal ions and silica may take place. The source of silica for chrysocolla, the main constituent of the paragenesis, is decomposition of rockforming minerals of both rhyolites and the surrounding shales. Oxidation of sulphides leads to the generation of $\mathrm{pH}$-low solutions. By such conditions, rock-forming aluminosilicate minerals undergo transformation rapidly. Migration of solutions outside the zones in direct contact with ore minerals undergoing oxidation and inflow of meteoric waters leads to an increase in $\mathrm{pH}$ of these solutions and binding of silica and $\mathrm{Cu}^{2+}$ ions in the form of chrysocolla (Schlomovitch et al., 1999; Crane et al., 2001; Števko et al., 2011). Precipitation of goethite is stabilized by an elevated $\mathrm{pH}$. Subordinate occurrences of mottramite are likely due to low concentrations of vanadate ions in solution. The source minerals of vanadium may be both rock-forming minerals (e.g., biotite) and magnetite, which is present in minor amounts in the deposit and its surroundings (Stauffacher, 1916; Hoehne, 1952; Manecki, 1965).

\section{CONCLUSIONS}

Parageneses of recently forming SCM reflect a diversity of geochemical conditions prevailing in abandoned mine galleries of the polymetallic metal mine in Radzimowice. Of the SCM group, the most common are HCS, usually accompanied by various amounts of malachite. This indicates relatively high activity of sulphate ions, associated with moderate amounts of carbonate ions. HCS may crystallise (1) directly from mine waters and (2) by transformation of previously formed cuprite and native copper, due to the action of sulphate-rich waters. The occurrence of rich accumulations of $\mathrm{Cu}-\mathrm{Al}$ sulphates and admixtures of $\mathrm{Al}$ in nominally $\mathrm{Al}$-free minerals (devilline, langite, posnjakite) demonstrates relatively high activity of $\mathrm{Al}^{3+}$ ions in solutions parental for SCM. The presence of aluminium is due to the decomposition of rock-forming aluminosilicates attacked by mine waters. The next factor influencing the formation of SCM is pH. In general, the crystallisation of HCS occurred at mildly acidic to neutral $\mathrm{pH}$. Cu-Al sulphates formed in zones where low-pH waters, chemically transformed due to the oxidation of ores, were mixing with neutral waters. Such zones represent natural geochemical barriers. Abundant dissolution traces and replacement textures document the effects of seasonal modifications of the chemical composition of the mine waters. These chemical variations reflect an increased inflow of waters that remain chemically unchanged due to weathering processes during humid seasons. The crystallisation and dissolution of these recently forming SCM play an important role in copper sequestration and release of copper into groundwaters.

Acknowledgements. The authors thank the reviewers: J.M. Hammarstrom and S.Z. Mikulski for their helpful discussion of the manuscript. The study was financed by the Ministry of Science and Higher Education grant NN307065934.

\section{REFERENCES}

Alwan A.K., Williams P.A. (1979) Mineral formation from aqueous solution, Part II. The stability of langite, $\mathrm{Cu}_{2} \mathrm{SO}_{4}(\mathrm{OH})_{6} \cdot \mathrm{H}_{2} \mathrm{O}$. Transition Metal Chemistry, 4: 319-322.

Baranowski Z. (1988) Lithofacies characteristics of trench-fill metasediments in the Radzimowice Slate (Paleozoic, Sudetes, SW Poland) (in Polish with English summary). Annales Societatis Geologorum Poloniae, 58: 325-383.

Basso R., Palenzona A., Zefiro L. (1989) Crystal structure refinement of Sr-bearing term related to copper vanadates and arsenates of adelite and descloizite groups. Neues Jahrbuch für Mineralogie Monatshefte, (7): 300-308.

Berg G. (1913) Beiträge zur Geologie von Niederschlesien mit besonderer Berücksichtigung der Erzlagerstätten. Abhandlungen der Preussischen Geologischen Landesanstalt, N.F., 74.
Bigham J.M., Schwertmann U., Traina S.J., Winland R.L., Wolf M. (1996) Schwertmannite and the chemical modeling of iron in acid sulfate waters. Geochimica et Cosmochimica Acta, 60: 2111-2121.

Bish D.L., Livingstone A. (1981) The crystal chemistry and paragenesis of honessite and hydrohonessite: the sulphate analogues of reeversite. Mineralogical Magazine, 44: 339-343.

Bowell R.J., Parshley J.C. (2005) Control of pit-lake water chemistry by secondary minerals, Summer Camp pit, Getchell mine, Nevada. Chemical Geology, 215: 373-385.

Bridges T.T., Green D.J. (2007) Zoned oxidation deposit in Tynebottom Mine, Garrigill, Cumbria. Journal of the Russell Society, 10: 2-9.

Brugger J., Armbruster T., Criddle A., Berlepsch P., Graeser S., Reeves S. (2001) Description, crystal structure, and para- 
genesis of krettnichite, $\mathrm{PbMn}^{3+}{ }_{2}\left(\mathrm{VO}_{4}\right)_{2}(\mathrm{OH})_{2}$, the $\mathrm{Mn}^{3+}$ analogue of mounanaite. European Journal of Mineralogy, 13: 145-158.

Clissold M.E., Leverett P., Williams P.A. (2005) Chemical mineralogy of the oxidized zones of the E22, E26 and E27 ore bodies at Northparkers, New South Wales. In: Procedings of the CRC Leme Regional Regolith Symposia 2005 (ed. I.C. Roach): $55-58$.

Crane M.J., Sharpe J.L., Williams P.A. (2001) Formation of chrysocolla and secondary copper phosphates in the highly weathered supergene zones of some Australian deposits. Records of the Australian Museum, 53: 49-56.

Crichton W.A., Müller H. (2008) New diffraction data: Brochantite-2M2 from Pierre Plate Mine, Vizille. Powder Diffraction, 23: $246-250$.

Cwojdziński S., Kozdrój W. (1994) Szczegółowa mapa geologiczna Sudetów w skali 1:25 000, arkusz Wojcieszów. Polska Agencja Ekologiczna. Warszawa.

Dabinett T.R., Humberstone D., Leverett P., Williams P.A. (2008) Synthesis and stability of wroewolfeite, $\mathrm{Cu}_{4} \mathrm{SO}_{4}(\mathrm{OH})_{6} \cdot 2 \mathrm{H}_{2} \mathrm{O}$. Pure and Applied Chemistry, 80: 1317-1323.

Dill H.G. (2009) Pyrometallurgical relicts of $\mathrm{Pb}-\mathrm{Cu}-\mathrm{Fe}$ deposits in south-eastern Germany: an exploration tool and a record of mining history. Journal of Geochemical Exploration, 100: 37-50.

Dinelli E., Morandi N., Tateo F. (1998) Fine-grained weathering products in waste disposal from two sulphide mines in the northern Apennines, Italy. Clay Minerals, 33: 423-433.

Downs R.T. (2006) The RRUFF Project: an integrated study of the chemistry, crystallography, Raman and infrared spectroscopy of minerals. Program and Abstracts of the 19th General Meeting of the International Mineralogical Association in Kobe, Japan: 3-13.

Fiedler H. (1863) Die Mineralien Schlesiens mit Berücksichtigung der angrenzenden Länder. Breslau: 1-121.

Fitzgerald K.P., Nairn J., Artens A. (1998) The chemistry of copper patination. Corrosion Science, 40: 2029-2050.

Fitzgerald K.P., Nairn J., Skennerton G., Atrens A. (2006) Atmospheric corrosion of copper and the colour, structure and composition of natural patinas on copper. Corrosion Science, 48: 2480-2509.

Frost R.L. (2003) Raman spectroscopy of selected copper minerals of significance of corrosion. Spectrochimica Acta, Part A, 59: 1195-1204.

Frost R.L., Reddy B.J., Keeffe E.C. (2010) Structure of selected basic copper(II) sulphate minerals based upon spectroscopy Implications for hydrogen bonding. Journal of Molecular Structure, 977: 90-99.

Fuente D., Simancas J., Morcillo M. (2008) Morphological study of 16-year patinas formed on copper in a wide range of atmospheric exposures. Corrosion Science, 50: 268-285.

Galy J., Jaud J., Pulou R., Sempère R. (1984) Structure cristalline de la langite, $\mathrm{Cu}_{4}\left[\mathrm{SO}_{4}(\mathrm{OH})_{6} \mathrm{H}_{2} \mathrm{O}\right] \cdot \mathrm{H}_{2} \mathrm{O}$. Bulletin de Minéralogie, 107: 641-648.

Gentsch M., Weber K. (1984) Structure of Langite, $\mathrm{Cu}_{4}\left[(\mathrm{OH})_{6} \mid \mathrm{SO}_{4}\right]$ $2 \mathrm{H}_{2} \mathrm{O}$. Acta Crystallographica C, 40: 1309-1311.

Ha H., Taxen C., Williams K., Scully J. (2011) Effects of selected water chemistry variables on copper pitting propagation in potable water. Electrochimica Acta, 56: 6165-6183.

Hammarstrom J.M., Seal II R.R., Meier A.L., Kornfeld J.M. (2005) Secondary sulfate minerals associated with acid drainage in the eastern US: recycling of metals and acidity in surficial environments. Chemical Geology, 215: 407-431.

Haydukiewicz A., Urbanek Z. (1986) The metamorphosed Devonian rocks in the Bolków unit (the Kaczawskie Mts, Sudetes) (in Polish with English summary). Geologia Sudetica, 20: 185-196.

Hoehne K. (1952) Vorkommen von Magnetit in Schlesien. Neues Jahrbuch für Geologie und Paläontologie Monatshefte, (7): 289-294.

Holeczek J., Janeczek J. (1991) Pseudomalachite from Radzimowice and some comments on its occurrence in Miedzianka (Sudetes Mts.). Mineralogia Polonica, 22: 17-26.

Kaş R., Birer Ö. (2012) Sonochemical shape control of copper hydroxysulfates. Ultrasonics Sonochemistry, 19: 692-700.
Kierczak J., Poysz A., Pietranik A., Tyszka R., Modelska M., Néel C., Etter V., Mihailevič M. (2012) Environmental impact of the historical $\mathrm{Cu}$ smelting in the Rudawy Janowickie Mountains (south-western Poland). Journal of Geochemical Exploration, 124: $183-194$

Klauber C., Parker A., Bronswijk W. van, Walting H. (2001) Sulphur speciation of leached chalcopyrite surfaces as determined by X-ray photoelectron spectroscopy. International Journal of Mineral Processing, 62: 65-94.

Komkov A.l., Nefedov E.I. (1967) Posnjakite, a new mineral. Zapiski Vsesoyuznogo Mineralogicheskogo Obschchestva, 96: 58-62 (in Russian). Zapiskach Vsesoyuznogo, 52: 1579-1589.

Kozdrój W., Krentz O., Opletal M. (2001) Comments on the Geological Map Lausitz-Izera-Karkonosze, 1:100 000. Polish Geological Institute, Warszawa.

Krause W., Kolitsch U., Bernhardt H.J., Effenberger H. (2003) Duhamelite discredited. Neues Jahrbuch für Mineralogie Monatshefte, (2): 75-96

Krätschmer A., Wallinder I.O., Leygraf C. (2002) The evolution of outdoor copper patina. Corrosion Science, 44: 425-450.

Lazebnik K.A., Zajakina N.W. (1988) Kalcevyi mottramit - pervyi predstavitel' novogo izomorfnogo mottramit-tangeitovago riada (in Russian). Doklady Akademii Nauk, 306: 434-438.

Machowiak K., Amstrong R., Kryza R., Muszyński A. (2008) Late-orogenic magmatism in the Central European Variscides: SHRIMP U-Pb zircon age constraints from the Żeleźniak intrusion, Kaczawa Mountains, West Sudetes. Geologia Sudetica, 40: 1-18.

Maley M., Bronswijk W. van, Watling H.R. (2009) Leaching of a low-grade, copper-nickel sulfide ore. 3. Interactions of $\mathrm{Cu}$ with selected sulfide minerals. Hydrometallurgy, 98: 73-80.

Manecki M. (1962) Intruzje lamprofirowe w okolicy Radzimowic na Dolnym Śląsku. Sprawozdania z Posiedzeń Komisji Naukowej PAN Oddział w Krakowie, 7: 538-539.

Manecki M. (1965) Mineralogical and petrographical study of ore veins of the vicinity of Wojcieszów (Lower Silesia) (in Polish with English summary). Prace Mineralogiczne, 2: 1-90.

Marani D., Patterson J.W., Anderson P.R. (1995) Alkaline precipitation and aging of $\mathrm{Cu}(\mathrm{II})$ in the presence of sulfate. Water Research, 29: 1317-1326.

Marini L., Saldi G., Cipolli F., Ottonello G., Zuccolini M.V. (2003) Geochemistry of water discharges from the Libiola mine, Italy. Geochemical Journal, 37: 199-216.

Mendoza A.R., Corvo F., Gómez A., Gómez J. (2004) Influence of the corrosion products of copper on its atmospheric corrosion kinetics in tropical climate. Corrosion Science, 46: 1189-1200.

Merkel T.H., Gross H.J., Werner W., Dahlke T., Reiocherter S., Beuchle G., Eberle S.H. (2002) Copper corrosion by-product release in long term stagnation experiments. Water Research, 36: $1547-1555$.

Mikulski S.Z. (2003) Multiple episodes of magmatic and hydrothermal activity at the Radzimowice gold deposit in the Sudetes Mountains (Bohemian Massif, Poland). In: Mineral Exploration and Sustainable Development: 339-342. Proceedings of the 7th Biennial SGA meeting, Athens, Greece, 24-28 August.

Mikulski S.Z. (2005a) Geological, mineralogical and geochemical characteristics of the Radzimowice Au-As-Cu deposit from the Kaczawa Mountains (Western Sudetes, Poland): an example of the transition of porphyry and epithermal style. Mineralium Deposita, 39: 904-920.

Mikulski S.Z. (2005b) The telluride mineralization event(s) within Late-Variscan gold deposits in the Western Sudetes (NE part of the Bohemian Massif, SW Poland). In: Mineral Deposit Research: Meeting the Global Challenge (eds. J. Mao and F.P. Bierlein): 1415-1418. Springer Verlag.

Mikulski S.Z. (2007) The late Variscan gold mineralization in the Kaczawa Mountains, Western Sudetes. Polish Geological Institute Special Papers, 22: 1-162.

Mikulski S.Z. (2011) Gold deposits in Kaczawa Mountains, West Sudetes, SW Poland. Archivum Mineralogiae Monograph, 2: 63-83. 
Mikulski S.Z., Muszyński A. (2012) Petzite $\left(\mathrm{Ag}_{3} \mathrm{AuTe}{ }_{2}\right)$ - a new telluride mineral from the Radzimowice deposit (Sudetes, SW Poland). Prace Specjalne Polskiego Towarzystwa Mineralogicznego, 40: 103-104.

Mikulski S.Z., Williams I.S. (2010) Lamprophyres from the Żelaźniak igneous rock suites (Kaczawa Mountains) - geochemistry, petrography and preliminary SHRIMP zircon ages. Prace Specjalne Polskiego Towarzystwa Mineralogicznego, 37: 50-51.

Mikulski S.Z., Stein H.J., Markey R.J. (2005a) Determination of sulphide ages from Lower Silesia using the Re-Os method. Prace Specjalne Polskiego Towarzystwa Mineralogicznego, 26: 215-218.

Mikulski S.Z., Markey R.J., Stein H.J. (2005b) Re-Os ages for auriferous sulphides from the gold deposits in the Kaczawa Mountains (SW Poland). In: Mineral Deposit Research: Meeting the Global Challenge (eds. J. Mao and F.P. Bierlein): 793-796. Springer Verlag.

Mills S.J., Kampf A.R., Pasero M., Merlino S. (2010) Discreditation of "orthobrochantite" (IMA78-64) as the MDO1 polytype of brochantite. European Journal of Mineralogy, 22: 453-457.

Murad E., Rojík P. (2003) Iron-rich precipitates in a mine drainage environment: influence of $\mathrm{pH}$ on mineralogy. American Mineralogist, 88: 1915-1918.

Nickel E.H. (1976) New data on woodwardite. Mineralogical Magazine, 43: 644-647.

Nordstrom D.K., Alpers C.N. (1999) Geochemistry of acid mine waters. Review of Economical Geology, 6A: 133-160.

Ondruš P., Veselovský F., Hloušek J., Skála R., Vavřín I., Fryda J., Čejka J., Gabašová A. (1997) Secondary minerals of the Jáchymov (Joachimsthal) ore district. Journal of Czech Geological Society, 42: 3-69.

Parafiniuk J. (1996) Sulfate minerals and their origin in the weathering zone of the pyrite bearing schists at Wieściszowice (Rudawy Janowickie Mts, Western Sudetes). Acta Geologica Polonica, 46: 353-414.

Parafiniuk J., Siuda R. (2006) Schwertmannite precipitated from acid mine drainage in the Western Sudetes (SW Poland) and its arsenate sorption capacity. Geological Quarterly, 50 (4): 475-486.

Paulo A., Salomon W. (1974) Contribution to the knowledge of a polymetallic deposit at Stara Góra (in Polish with English summary). Kwartalnik Geologiczny, 18 (2): 266-276.

Pollard A.M., Thomas R.G., Williams P.A. (1992) The stabilities of antlerite and $\mathrm{Cu}_{3} \mathrm{SO}_{4}(\mathrm{OH})_{4} \cdot 2 \mathrm{H}_{2} \mathrm{O}$ : their formation and relationship to other copper(II) sulphate minerals. Mineralogical Magazine, 56: 359-365.

Pulou R., Sempère R., Tournemire R. (1978) Découverte de langite dans I'Aveyron. Bulletin de Minéralogie, 101: 577-578.

Raade G., Elliott C.J., Din V.K. (1985) New data on glaucocerinite. Mineralogical Magazine, 49: 583-590.

Rietveld H.M. (1967) Line profiles of neutron powder-diffraction peaks for structure refinement. Acta Crystallographica, 22: 151-152.

Řídkošil T., Povondra P. (1982) The relationship between posnjakite and langite. Neues Jahrbuch für Mineralogie Monatshefte, (1): 16-28.

Schmidt M., Lutz H.D. (1993) Hydrogen bonding in basic copper salts: a spectroscopic study of malachite, $\mathrm{Cu}_{2}(\mathrm{OH})_{2}\left(\mathrm{CO}_{3}\right)$, and brochantite, $\mathrm{Cu}_{4}(\mathrm{OH})_{6} \mathrm{SO}_{4}$. Physics and Chemistry of Minerals, 20: 27-32.

Sejkora J., Ďud'a R., Novotná M. (2001) Minerals of oxide zone of the Križová vein, Gelnica, the Slovenské Rudohorie Mts., Slovak Republic (in Czech). Bulletin mineralogickogopetrologického oddlení Národního muzea v Praze, 9: 121-139.
Sejkora J., Ondruš P., Fikar M., Veselovský F., Mach Z., Gabašova A., Škoda R., Beran P. (2006) Supergene minerals at the Huber stock and Schnöd stock deposits, Krásno ore district, the Slavkovský les area, Czech Republic. Journal of the Czech Geological Society, 51: 57-101.

Shlomovitch N., Bar-Matthews M., Segev A., Matthews A. (1999) Sedimentary and epigenetic copper mineral assemblages in the Cambrian Timna Formation, southern Israel. Israel Journal of Earth Sciences, 48: 195-208.

Siuda R. (2001) New sulphate minerals from the Stara Góra oxidised zone, Radzimowice, Kaczawskie Mts. Prace Specjalne Polskiego Towarzystwa Mineralogicznego, 18: 186-188.

Siuda R. (2004) Iron arsenates from Stara Góra deposit at Radzimowice in Kaczawa Mountains, Poland - a preliminary report. Prace Specjalne Polskiego Towarzystwa Mineralogicznego, 24: 345-348.

Siuda R., Kruszewski Ł. (2005) Arsenate mottramite from the Stara Góra deposit (Kaczawa Mts., Poland) - preliminary report. Prace Specjalne Polskiego Towarzystwa Mineralogicznego, 26: 260-264.

Stara P., Rizzo R., Sabelli C., Ibba A. (1999) I minerali di Funtana Raminosa (Gadoni, Sardegna Centrale). Rivista Mineralogica Italiana, 1: 10-27.

Stauffacher J. (1916) Der Goldgangdistrikt von Altenberg in Schlesien. Zeitschrift für praktische Geologie, 23: 53-88.

Sylwestrzak H., Wołkowicz K. (1985) A new assemblage of Sn-W-Mo minerals from Stara Góra (Lower Silesia) and its genetic significance (in Polish with English summary). Przegląd Geologiczny, 33: 73-75.

Šatović D., Martinez S., Bobrowski A. (2010) Electrochemical identification of corrosion products on historical and archeological bronzes using the voltammetry of micro-particles attached to a carbon paste electrode. Talanta, 81: 1760-1765.

Števko M., Sejkora J., Bačík P. (2011) Mineralogy and origin of supergene mineralization at the Farbište ore occurrence near Poniky, central Slovakia. Journal of Geosciences, 56: 273-298.

Taxén C., Letelier M.V., Lagos G. (2012) Model for estimation of copper release to drinking water from copper pipes. Corrosion Science, 58: 267-277.

Traube H. (1888) Die Minerale Schlesiens (in German). J.U. Kern's Verlag (Max Miller), Breslau.

Triantafyllidis S., Skarpelis N. (2006) Mineral formation in an acid pit lake from a high-sulfidation ore deposit: Kirki, NE Greece. Journal of Geochemical Exploration, 88: 68-71.

Tumiati S., Godard G., Masciocchi N., Martin S., Monticelli D. (2008) Environmental factors controlling the precipitation of $\mathrm{Cu}$-bearing hydrotalcite-like compounds from mine waters. The case of the "Eve verda" spring (Aosta Valley, Italy). European Journal of Mineralogy, 20: 73-94.

Urbanek Z., Baranowski Z. (1986) Revision of age of the Radzimowice slates from Góry Kaczawskie Mts. (Western Sudetes, Poland). Annales Societatis Geologorum Poloniae, 56: 399-408.

Vink B.W. (1986) Stability relations of malachite and azurite. Mineralogical Magazine, 50: 41-47.

Williams S.A. (1964) A new occurrence of langite. American Mineralogist, 49: 1143-1145.

Woods T.L., Garrels R.M. (1986) Phase reactions in some cupric hydroxy minerals. Economic Geology, 81: 1989-2007.

Yu J.Y., Heo B., Choi I.K., Cho J.P., Chang H.W. (1999) Apparent solubilities of schwertmannite and ferrihydrite in natural stream waters polluted by mine drainage. Geochimica et Cosmochimica Acta, 63: 3407-3416.

Zimnoch E. (1965) New data on the ore mineralization of deposit at Stara Góra (in Polish with English summary). Biuletyn Geologiczny Wydziału Geologii UW, 5: 3-38. 